\title{
Climate and vegetation history of western Portugal inferred from Albian near-shore deposits (Galé Formation, Lusitanian Basin)
}

\author{
ULRICH HEIMHOFER* $\dagger$, PETER-A. HOCHULI $\ddagger$, STEFAN BURLA $\S$, \\ FELIX OBERLIף, THIERRY ADATTE\|, JORGE L. DINIS\# \& HELMUT WEISSERT $~$ \\ * Institute of Geology, Leibniz University Hannover, 30167 Hannover, Germany \\ $\ddagger$ Palaeontological Institute, University of Zürich, CH-8006 Zürich, Switzerland \\ $\S$ Geological Institute, ETH Zürich, CH-8092 Zürich, Switzerland \\ -Institute of Geochemistry and Petrology, ETH Zürich, CH-8092 Zürich, Switzerland \\ |Institute of Geology and Palaeontology, Université de Lausanne, CH-1015 Lausanne, Switzerland \\ \#Departamento de Ciências da Terra, Universidade de Coimbra, 3000 Coimbra, Portugal
}

(Received 22 July 2011; accepted 24 January 2012; first published online 1 May 2012)

\begin{abstract}
The late Early Cretaceous greenhouse climate has been studied intensively based on proxy data derived essentially from open marine archives. In contrast, information on continental climatic conditions and on the accompanying response of vegetation is relatively scarce, most notably owing to the stratigraphic uncertainties associated with many Lower Cretaceous terrestrial deposits. Here, we present a palynological record from Albian near-shore deposits of the Lusitanian Basin of W Portugal, which have been independently dated using Sr-isotope signals derived from low-Mg oyster shell calcite. ${ }^{87} \mathrm{Sr} /{ }^{86} \mathrm{Sr}$ values fluctuate between $0.707373 \pm 0.00002$ and $0.707456 \pm 0.00003$; absolute values and the overall stratigraphic trend match well with the global open marine seawater signature during Albian times. Based on the new Sr-isotope data, existing biostratigraphic assignments of the succession are corroborated and partly revised. Spore-pollen data provide information on the vegetation community structure and are flanked by sedimentological and clay mineralogical data used to infer the overall climatic conditions prevailing on the adjacent continent. Variations in the distribution of climate-sensitive pollen and spores indicate distinct changes in moisture availability across the studied succession with a pronounced increase in hygrophilous spores in late Early Albian times. Comparison with time-equivalent palynofloras from the Algarve Basin of southern Portugal shows pronounced differences in the xerophyte/hygrophyte ratio, interpreted to reflect the effect of a broad arid climate belt covering southern and southeastern Iberia during Early Albian times.
\end{abstract}

Keywords: Albian Stage, Sr-isotopes, palynology, clay mineralogy, palaeoclimate, Portugal.

\section{Introduction}

The Albian Age (112.0-99.6 Ma, Gradstein, Ogg \& Smith, 2004) is generally viewed as a time characterized by a long-term increase of global temperatures, finally culminating in the Late Cretaceous thermal maximum (Huber, Hodell \& Hamilton, 1995; Pucéat et al. 2003; Forster et al. 2007). Stratigraphically well-calibrated marine proxy records provide evidence for significant short-term fluctuations in tropical and boreal ocean water temperatures, which occur superimposed on the general warming trend during Albian times (Clarke \& Jenkyns, 1999; Bice et al. 2006; Erbacher et al. 2011). Furthermore, deposition in the Tethys and the evolving North Atlantic Ocean was characterized by the repeated formation of organiccarbon-rich deposits, particularly during earliest and latest Albian times, known as Oceanic Anoxic Events $1 \mathrm{~b}$ and d, respectively (e.g. Wilson \& Norris, 2001; Herrle et al. 2003). These short-lasting events had a profound impact on marine biogeochemical cycles and were often associated with significant temperature

$\dagger$ †uthor for correspondence: heimhofer@geowi.uni-hannover.de anomalies (Erbacher et al. 2001; Wagner et al. 2007; Hofmann et al. 2008). Major marine bio-events taking place in the course of the Albian affect planktonic foraminifera, radiolarians and calcareous nannofossils (Erbacher, Thurow \& Littke, 1996; Tiraboschi, Erba \& Jenkyns, 2009; Huber \& Leckie, 2011). On land, this time interval was associated with the rising dominance of angiosperms in terrestrial ecosystems (Crane, Friis $\&$ Pedersen, 1995). The radiation and diversification of early angiosperms during Albian times had a strong impact on the coexisting plant communities, clearly visible in the concomitant decline of gymnosperm pollen and pteridophyte spores (Crane \& Lidgard, 1989).

Compared to the marine realm, information on the climatic conditions prevailing on the continents during Albian times is relatively scarce. This results mainly from the difficulties associated with the stratigraphic assignment of Lower Cretaceous continental deposits, essentially caused by the lack of suitable age-diagnostic marker fossils. Furthermore, correlation with stratigraphically well-constrained marine strata is hampered by the frequent occurrence of hiatuses, highlighting the incompleteness of the continental sedimentary record. 
However, some of these problems can be circumvented by studying near-shore marine deposits, which provide terrestrial climate signals in the form of spore-pollen assemblages and clay minerals.

The stratigraphic assignment of shallow marine palynomorph-bearing deposits can be significantly improved by the use of Sr-isotope stratigraphy (Burla et al. 2009). Sr-isotope values of low-Mg calcite fossils (e.g. brachiopods, belemnites, bivalves) reflect past seawater ${ }^{87} \mathrm{Sr} /{ }^{86} \mathrm{Sr}$ ratios (e.g. Jones et al. 1994; Veizer et al. 1999; Korte et al. 2003). Hence, temporal fluctuations in ${ }^{87} \mathrm{Sr} /{ }^{86} \mathrm{Sr}$ ratios can serve as an independent chronostratigraphic tool. In the last couple of years, the ${ }^{87} \mathrm{Sr} /{ }^{86} \mathrm{Sr}$ ratios of well-preserved rudist shells have been successfully utilized to date Cretaceous shoalwater carbonate platform deposits lacking accurate biostratigraphic constraints (Steuber et al. 2005; Huck et al. 2011). In more detritus-influenced depositional systems, the use of ${ }^{87} \mathrm{Sr} /{ }^{86} \mathrm{Sr}$ ratios from oyster shell low-Mg calcite represents a valuable alternative. A number of studies have demonstrated that oyster shells represent a reliable carrier of the Mesozoic seawater Sr-isotope signal (Jones et al. 1994; Denison et al. 2003; Burla et al. 2009; Schneider, Fürsich \& Werner, 2009) and therefore hold a significant potential for the stratigraphic refinement of Mesozoic near-shore successions.

The Lusitanian Basin of western Portugal is a key area for the study of early angiosperm remains. Here, the discovery of a series of exceptionally preserved angiosperm mesofossil floras in the northern part has strongly influenced the current understanding of the evolutionary relationships and biology of early angiosperms (Friis, Pedersen \& Crane, 2010) (Fig. 1). In contrast, the southern part of the basin bears nearshore marine deposits, which contain a well-preserved late Early Cretaceous palynoflora including a rich angiosperm pollen assemblage (Groot \& Groot, 1962; Medus \& Berthou, 1980; Medus, 1982; Trincão, 1990; Heimhofer et al. 2005, 2007). Together with the classical Potomac record (Doyle \& Robbins, 1977; Hochuli, Heimhofer \& Weissert, 2006), the Portuguese angiosperm pollen records from the Rodízio and Galé formations are regarded as a reference succession for the palynological changes observed in mid-latitude angiosperm palynofloras during Albian times (Field, Chatelet \& Brodribb, 2009).

The aim of this study is twofold: (1) Establish a refined stratigraphic framework using Sr-isotope stratigraphy based on low-Mg calcite oyster shells for the Albian deposits of the Guincho section; (2) Provide information on the floral community structure and on the climatic history of the area based on total spore-pollen associations and clay mineral data. The integration of the new stratigraphic and palaeoclimatic findings with existing results on the angiosperm palynoflora will provide a better understanding of the temporal and palaeoclimatic context under which the Albian diversification of angiosperms took place.

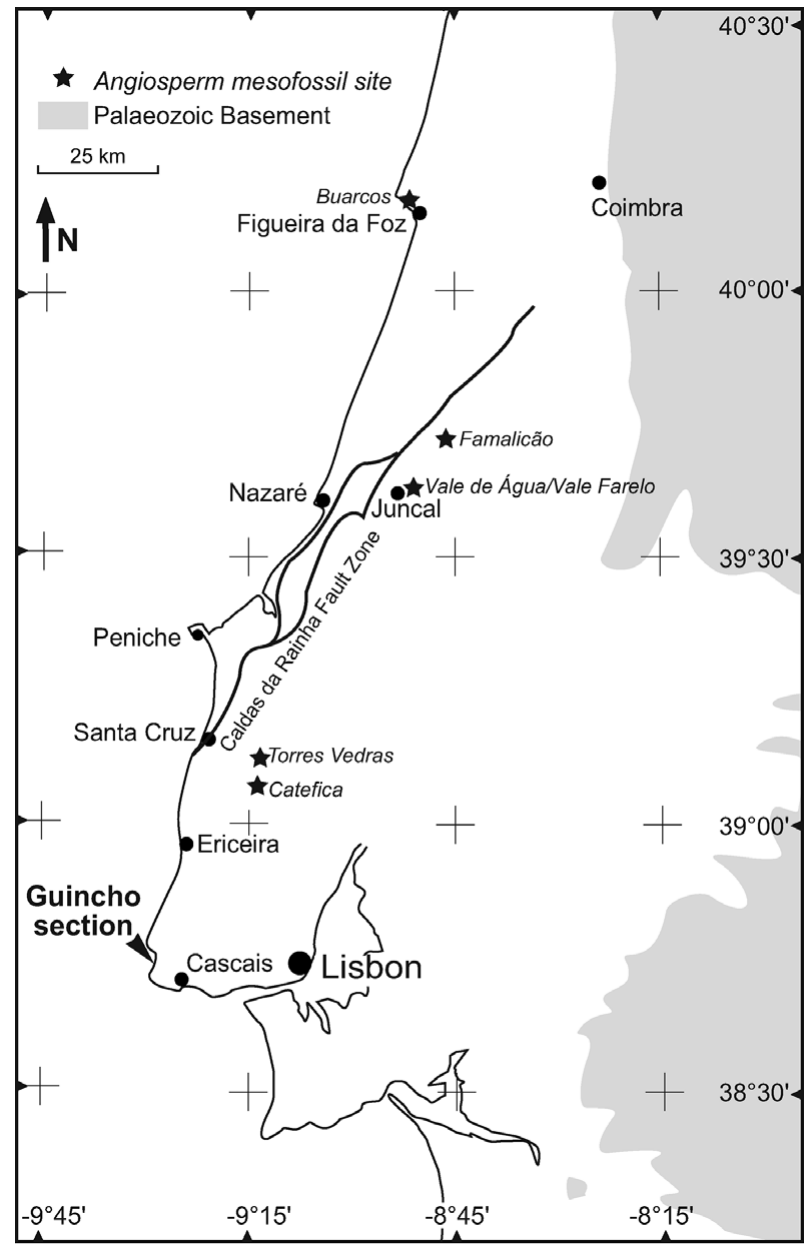

Figure 1. Map of western Portugal showing the location of the coastal outcrop of the Guincho section. Asterisks correspond to sites bearing Early Cretaceous angiosperm mesofossils. Map modified after Heimhofer et al. (2007) and Friis, Pedersen \& Crane (2010).

\section{Geological setting}

Lower Cretaceous sediments are well exposed in coastal outcrops of the Lusitanian Basin of Portugal. During Mesozoic times, the opening of the Atlantic Ocean resulted in the formation of a passive margin in western Iberia. In late Early Cretaceous times, thermally-induced basement uplift and isostatic adjustment led to the development of a basin-wide break-up unconformity in the Lusitanian Basin, followed by an episode of continental siliciclastic deposition directly overlying the unconformity (Dinis \& Trincão, 1995). The subsequent long-term eustatic rise allowed the reestablishment of near-shore marine conditions with deposition of mixed carbonate-siliciclastic sediments that are the focus of this study.

The sedimentary succession investigated covers more than $125 \mathrm{~m}$ of Albian strata and is accessible along the cliffs north of Cabo Raso, about $5 \mathrm{~km}$ northwest of the village of Cascais (Fig. 1). Here, an essentially continuous section (referred to as Guincho section) crops out along the beach of Praia de Água Doce between the Forte de Cresmina and the Ponta da Galé (Rey, Bilotte \& Peybernes, 1977; Rey, 1992). 


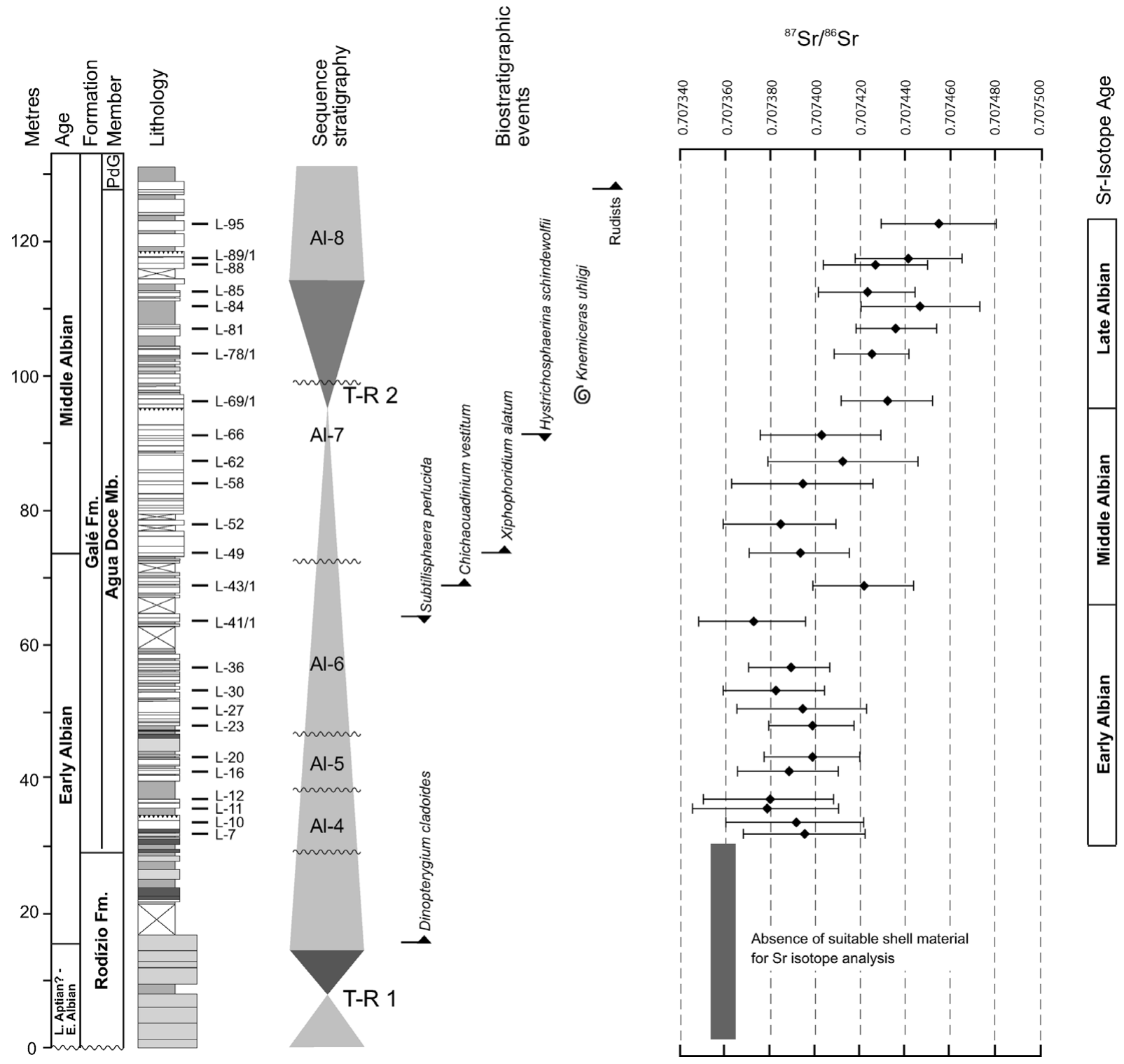

Figure 2. Simplified lithological log and lithostratigraphy of the Guincho section plotted against sequence-stratigraphy, first- and last occurrences of age-diagnostic dinoflagellate cysts and Sr-isotope ratios derived from oyster shell calcite. Both the previous (left-hand column) and the revised age assignment (right-hand column) are shown. Sequence-stratigraphy based on Dinis, Rey \& de Graciansky (2002) and Rey (2006); biostratigraphy based on Heimhofer et al. (2007). PdG - Ponta da Galé Member.

Following Rey, Bilotte \& Peybernes (1977) and Rey $(1992,2006)$ the section covers the Rodízio and the Gale formations with the latter being subdivided into two major lithological units, the Água Doce and Ponta da Galé members (Fig. 2). The Rodízio Formation covers the lowermost part of the section $(0-29 \mathrm{~m})$ and consists of thick-bedded and coarsegrained siliciclastic sediments with thin clayey and lignite-rich interbeds. At the studied locality, two fining-upward cycles can be differentiated, which consist of fluvial large-scale cross-bedded deposits, starting with conglomerates and passing into sandstones. The 18 to $22 \mathrm{~m}$ part of the section is currently not cropping out, being covered by beach sands.

The upper part of the Rodízio Formation, making the transition to the Água Doce Member of the Galé Formation, is characterized by a succession $(22-29 \mathrm{~m})$ of reddish and grey sand- and siltstones alternating with purple to greenish claystones interpreted to reflect deposition in peritidal and/or coastal settings (Dinis, Rey \& de Graciansky, 2002). This siliciclastic-dominated interval is overlain by the Água Doce Member, formed between $29 \mathrm{~m}$ and $71 \mathrm{~m}$ by fossiliferous inner shelf marls and sandy limestones, which alternate with varicoloured mudstones and sparse silt- or sandstone beds. The marls and limestones are strongly bioturbated and characterized by a rich macrofossil assemblage including oysters, gastropods, serpulids, thick-shelled bivalves and orbitolinids. Within this interval, a unit composed of thin-bedded ochre-coloured sand- and siltstones can be distinguished ( $43.5 \mathrm{~m}$ to $45.5 \mathrm{~m}$ ). Abundant ripple structures and a fine lamination pattern as well as the occurrence of highly oxidized wood fragments point to deposition in a shallow, high-energy environment. 
At $\sim 71 \mathrm{~m}$, the lithologically heterogeneous lower part of the Água Doce Member passes into inner shelf marls and limestones. The subsequent series (71-97.5 m) is dominated by thick-bedded and fossilrich limestones, alternating with more marly or sandrich interbeds. The limestones have a very distinct nodular appearance, most probably caused by intensive burrowing. This lithology is rich in large orbitolinids, gastropods and bivalves, whereas oysters, miliolinids and echinid remains are of subordinate importance. The limestone-dominated interval ends abruptly and is overlain by a succession of varicoloured peritidal mud- and siltstones with sandy and marly limestone intercalations $(97.5-113 \mathrm{~m})$. In this unit, the top of individual limestone beds is frequently marked by thick-shelled oyster colonies, often preserved in growth position. The greenish to dark-grey mudstones are characterized by millimetre-scale lamination, whereas the marly and sandy lithologies display intense bioturbation. This variegated interval passes again into thick-bedded limestones with thin clayey interbeds $(113-131 \mathrm{~m})$. The fossil content includes abundant oysters and other bivalves, echinoderm debris, gastropods, miliolinids and orbitolinids. The uppermost limestone bed $(128 \mathrm{~m})$ is characterized by abundant rudists, occurring reworked as well as in growth position, and serves as a distinct marker bed, namely as the lowermost bed of the Ponta da Galé Member.

The investigated succession has been studied in detail from a bio- and sequence-stratigraphic perspective by Rey, Bilotte \& Peybernes (1977), Berthou \& Schroeder (1979), Berthou \& Leereveld (1990), Rey (1992, 2006) and Dinis, Rey \& de Graciansky (2002). According to a revised biostratigraphic framework based on dinoflagellate cyst assemblages (Heimhofer et al. 2007), the upper part of the Rodízio Formation is characterized by an age not older than Early Albian, not excluding a Late Aptian age for its lower part. The overlying Água Doce Member is considered to be of Early and Middle Albian age. Biostratigraphic evidence derived from dinoflagellate cysts does not provide evidence for Upper Albian strata in the studied part of the succession.

Based on the sequence-stratigraphic interpretation of Dinis, Rey \& de Graciansky (2002) and Rey, de Graciansky \& Jacquin (2003), the studied section covers at least two second-order transgressive-regressive cycles (Fig. 2). A first progradational-retrogradational sequence is covered by the lower part of continental siliciclastic sediments of the Rodízio Formation. A second sequence is characterized by an extensive transgressive $(\sim 15-97.5 \mathrm{~m})$ and a short regressive part and covers the upper Rodízio Formation and most of the Água Doce Member. The uppermost part of the studied succession corresponds to the transgressive part of a third second-order cycle, including the top of the Água Doce and the lowermost levels of the Ponta da Galé Member.

\section{Palaeogeographic and palaeoclimatic framework}

During late Early Cretaceous times, the Iberian Peninsula was situated at a palaeolatitude between $25^{\circ}$ and $35^{\circ} \mathrm{N}$ (Sewall et al. 2007) and during most of this period formed part of an archipelago, which resulted from the expansion of epicontinental shallow seas during times of high sea-level (Chumakov et al. 1995; Hay et al. 1999). The Lusitanian Basin formed part of the eastern passive margin of the evolving North Atlantic and was strongly influenced by tectonic movements resulting in several regional unconformities and transgressive-regressive cycles (Dinis et al. 2008).

Generally, the late Early Cretaceous is considered a time characterized by exceptional global warmth as expressed in low equator-pole thermal gradients, high atmospheric $\mathrm{CO}_{2}$ levels and the absence of large continental ice sheets (e.g. Huber, Hodell \& Hamilton, 1995; Price, 1999; Haworth et al. 2005; Forster et al. 2007; Herman \& Spicer, 2010). Following a phase of pronounced aridity during the Barremian to Aptian interval (Ruffell \& Batten, 1990), also demonstrated to occur on the western Iberian margin (Berthou, Blanc \& Chamley, 1982), the southward migration of the equatorial humid belt during Late Aptian to Albian times reflects a significant change in the overall palaeoclimatic patterns (Chumakov et al. 1995). According to the palaeoclimatic reconstructions of the latter authors, the southern part of Iberia was located within a broad zone of arid to semi-arid conditions (Northern Hot Arid belt, NHA), even with developed erg systems (Rodríguez-López et al. 2008, 2010), whereas the northern part was within the Northern Midlatitude Warm humid belt (NMW) during Albian times.

Based on findings of plant macro-remains and on palynological assemblages from the Iberian Peninsula, different types of palaeovegetation and associated environments have been distinguished e.g. (Diéguez, Peyrot \& Barrón, 2010). These include forest communities dominated by Taxodiaceae-Cupressaceae thriving in riparian or mangrove habitats as well as conifer forests composed of Cheirolepidaceae and tree ferns reflecting more stressed conditions (Peyrot et al. 2007). On the other hand, freshwaterrelated environments like back swamps or riverbanks were populated by hygrophilous plant communities including Bryophyta, Lycophyta and various types of ferns as well as plants assigned to the Cycadales/Ginkoales/Bennettitales complex and early angiosperms (Coiffard, Gomez \& Thevenard, 2007; Villanueva-Amadoz et al. 2010). In summary, the vegetation was characteristic of a winter-wet biome under a semi-arid subtropical climate (Diéguez, Peyrot \& Barrón, 2010).

\section{Materials and methods}

\section{4.a. Strontium isotope stratigraphy}

For the analysis of the strontium isotope composition, a total of 25 visually well-preserved oysters were 
collected from the Água Doce Member of the Galé Formation. Oysters are relatively abundant in the detritus-rich shoal-water deposits and inner shelf limestones of the Guincho section, often occurring in the form of regular pavements covering entire bedding planes. Oysters collected from the succession belong to the genus Exogyra and Ostrea (Rey \& Cugny, 1978) and occur throughout the entire Galé Formation providing an essentially continuous coverage of the studied strata. Only the lowermost part of the Água Doce Member and the siliciclastic sediments of the Rodízio Formation were devoid of suitable shell material.

Oysters precipitate a shell consisting of low- $\mathrm{Mg}$ calcite and composed of individual foliate and prismatic layers (Carter, 1990). The specific mineralogy makes their calcitic shells relatively robust against subsequent diagenetic alteration processes which may affect the primary chemical composition of the shell material. Therefore, oyster shell calcite is considered a reliable carrier of the seawater Sr-isotope signal as demonstrated by previous studies (Jones et al. 1994; Veizer et al. 1999; Denison et al. 2003; Burla et al. 2009; Schneider, Fürsich \& Werner, 2009). However, conventional sampling of thin-shelled oysters can result in contamination by adjacent substrate and/or altered shell material or in insufficient sampling amounts. To circumvent this problem, a system combining laser ablation (LA) with multi-collector inductively coupled plasma mass spectrometry (MC-ICP-MS) was used for this study, which yields precise and accurate $\mathrm{Sr}$-isotope data at a high spatial resolution (e.g. Christensen et al. 1995; Woodhead et al. 2005; Burla et al. 2009).

Following visual inspection, the selected oyster shells were carefully cleaned to remove matrix material. Cleaned shells were cut using a diamond saw, placed on a specimen slide and polished. Following conventional petrographic inspection, all shell samples were investigated using a cold cathode luminescence (CL) optical system (Technosyn CL8200 MK II) at ETH Zurich, Switzerland. Only non-luminescent shell portions of the inner, foliate shell layer where used for subsequent laser ablation sampling.

Sr-isotope compositions were measured on a $\mathrm{Nu}$ Plasma 1700 MC-ICP-MS coupled to an Excimer $193 \mathrm{~nm}$ ArF laser (see Burla et al. 2009 for details). Guided by prior CL mapping, typically 15 spots were located on each sample and ablated for 50 seconds each (120 $\mu \mathrm{m}$ spot size). The measurements were internally corrected for mass bias and interference by $\mathrm{Rb}, \mathrm{Kr}$ and $\mathrm{Ca}$ argides, using equations given in Burla et al. (2009 and online supporting information). Groups of one to five sample measurements were bracketed by measurements on recent oyster shell material, the latter yielding a mean ${ }^{87} \mathrm{Sr} r{ }^{86} \mathrm{Sr}$ ratio of $0.709161 \pm 0.000016$ (external reproducibility at 1 standard deviation, $\mathrm{n}=$ 16). With the use of these bracketing standards, a renormalization to a value of 0.709175 was carried out on the samples in order to minimize ratio drift and to render the data compatible for comparison with the LOWESS model for seawater Sr evolution
(Howarth \& McArthur, 1997; McArthur, Howarth \& Bailey, 2001). Precision for runs on pristine samples ranges from \pm 0.000008 to $\pm 0.000016(1 \sigma$; Table 1$)$ and includes an error component from the renormalization procedure. Average external reproducibility calculated from repeated measurements on nine different samples from a companion study (Burla et al. 2009) was $\pm 0.000009(1 \sigma)$.

\section{4.b. Palynology}

A total of 36 rock samples from the Guincho section were prepared for palynological analysis. Despite the selection of apparently well-suited samples (including fresh medium- to dark-grey silt- and claystones), 16 samples were barren of palynomorphs. Cleaned, crushed and weighed samples ( 20 to $80 \mathrm{~g}$ ) were treated with $\mathrm{HCl}$ and $\mathrm{HF}$ following standard palynological preparation techniques (e.g. Traverse, 2007). All 20 productive samples were studied for their sporomorph content (spores and pollen). A minimum of 200 (average of 240) sporomorphs were determined and counted per slide. Light photomicrographs were taken using an Olympus BX 51 light microscope (LM) equipped with an Olympus DP 12 digital camera. The preservation of the studied palynomorphs is fairly good to excellent. Individual grains exhibit no obvious signs of post-depositional degradation. Thermally unaltered preservation of organic matter is indicated by the virtually unchanged colouring of the palynomorphs (TAI $<2$ according to the thermal alteration index of Staplin, 1982).

\section{4.c. Clay mineralogy}

A total of 25 samples from the Guincho section were analysed for their clay mineralogy. Clay mineral analyses were based on methods described by Adatte, Stinnesbeck \& Keller (1996). Ground chips were mixed with deionized water $(\mathrm{pH} 7-8)$ and agitated. The carbonate fraction was removed by addition of $10 \% \mathrm{HCl}$ at room temperature for 20 minutes or longer until all the carbonate was dissolved. Ultrasonic disaggregation was accomplished during 3 minute intervals. The insoluble residue was washed and centrifuged (5-6 times) until a neutral suspension was obtained ( $\mathrm{pH} 7-8)$. Separation of two different grainsize fractions $(<2 \mu \mathrm{m}$ and $2-16 \mu \mathrm{m})$ was obtained by the timed settling method based on Stokes law. The selected fraction was then pipetted onto a glass plate and air-dried at room temperature. X-ray diffraction (XRD) analysis of oriented clay samples were carried out after air drying at room temperature and under ethylene-glycol solvated conditions. The intensities of selected XRD peaks characterizing each clay mineral present in the size fraction (e.g. chlorite, mica, kaolinite and illite/smectite mixed-layers) were measured for a semi-quantitative estimate of the proportion of clay minerals present in two size fractions $(<2 \mu \mathrm{m}$ and $2-16 \mu \mathrm{m})$. Determination of the illite/smectite $(\mathrm{I} / \mathrm{S})$ 
Table 1. Strontium isotopic results for the Água Doce Member of the Galé Formation

\begin{tabular}{|c|c|c|c|c|c|c|c|c|}
\hline \multirow[b]{2}{*}{ Sample } & \multirow[b]{2}{*}{ Fm. member } & \multirow[b]{2}{*}{ Height [m] } & \multirow[b]{2}{*}{${ }^{87} \mathrm{Sr} /{ }^{86} \mathrm{Sr}$} & \multirow[b]{2}{*}{$2 \sigma$} & \multicolumn{3}{|c|}{ LOWESS ages [Ma] } & \multirow[b]{2}{*}{ Stage } \\
\hline & & & & & Age & Lower limit & Upper limit & \\
\hline L-7 & Água Doce & 30.7 & 0.707396 & 0.000027 & 108.6 & 93.5 & 110.1 & Early Albian \\
\hline L-10 & Água Doce & 32.4 & 0.707392 & 0.000030 & 108.8 & 93.2 & 110.3 & Early Albian \\
\hline L-11 & Água Doce & 34.4 & 0.707379 & 0.000032 & 109.4 & 104.7 & 110.8 & Early Albian \\
\hline L-12 & Água Doce & 35.8 & 0.707381 & 0.000028 & 109.3 & 105.1 & 110.6 & Early Albian \\
\hline L-16 & Água Doce & 40.0 & 0.707389 & 0.000022 & 109.0 & 104.7 & 110.2 & Early Albian \\
\hline L-20 top & Água Doce & 42.1 & 0.707400 & 0.000021 & 108.3 & 102.7 & 109.8 & Early Albian \\
\hline L-23 & Água Doce & 46.6 & 0.707400 & 0.000019 & 108.3 & 103.4 & 109.7 & Early Albian \\
\hline L-27 top & Água Doce & 49.3 & 0.707395 & 0.000028 & 108.6 & 93.4 & 110.2 & Early Albian \\
\hline L-30 & Água Doce & 52.0 & 0.707383 & 0.000022 & 109.2 & 105.6 & 110.3 & Early Albian \\
\hline L-36 & Água Doce & 55.4 & 0.707390 & 0.000018 & 108.9 & 105.3 & 110.0 & Early Albian \\
\hline L-41/1 & Água Doce & 62.2 & 0.707373 & 0.000023 & 109.6 & 107.7 & 110.7 & Early Albian \\
\hline L-43/1 & Água Doce & 67.6 & 0.707422 & 0.000022 & 104.7 & 94.6 & 108.9 & Middle Albian \\
\hline L-49 & Água Doce & 72.4 & 0.707394 & 0.000022 & 108.7 & 103.7 & 108.0 & Middle Albian \\
\hline L-52 & Água Doce & 76.7 & 0.707386 & 0.000025 & 109.1 & 104.9 & 110.3 & Middle Albian \\
\hline L-58 & Água Doce & 82.7 & 0.707396 & 0.000031 & 108.6 & 93.3 & 110.2 & Middle Albian \\
\hline L-62 & Água Doce & 86.0 & 0.707413 & 0.000033 & 107.0 & 93.8 & 109.7 & Middle Albian \\
\hline L-66 & Água Doce & 89.9 & 0.707404 & 0.000026 & 108.0 & 93.7 & 109.8 & Middle Albian \\
\hline L-69/1 & Água Doce & 95.0 & 0.707433 & 0.000020 & NA & 95.5 & 108.2 & NA \\
\hline L-78/1 & Água Doce & 102.0 & 0.707426 & 0.000016 & 103.8 & 95.3 & 108.4 & Late Albian \\
\hline L-81 & Água Doce & 105.8 & 0.707437 & 0.000018 & NA & 95.9 & 107.7 & NA \\
\hline L-84 & Água Doce & 109.0 & 0.707447 & 0.000026 & NA & 96.1 & 107.6 & NA \\
\hline L-85 & Água Doce & 111.2 & 0.707424 & 0.000021 & 104.2 & 94.8 & 108.8 & Late Albian \\
\hline L-88 & Água Doce & 115.2 & 0.707428 & 0.000023 & 103.4 & 94.9 & 108.7 & Late Albian \\
\hline L-89/1 & Água Doce & 116.2 & 0.707442 & 0.000024 & NA & 95.9 & 107.7 & NA \\
\hline L-95 & Água Doce & 121.3 & 0.707456 & 0.000025 & NA & 97.2 & 105.3 & NA \\
\hline
\end{tabular}

After internal correction for instrumental mass fractionation using ${ }^{88} \mathrm{Sr} /{ }^{86} \mathrm{Sr}$, the data have been normalized to a value of 0.709175 based on standard-sample bracketing, using modern oyster shells as standard (for details see Burla et al. 2009 and online supporting information).

The LOWESS ages (Howarth \& McArthur, 1997; McArthur, Howarth \& Bailey, 2001) and their bracketing values are derived from Look-Up Table Version 4: 08 / 04, the latter by combining 2 $\sigma$ measurement uncertainties with error envelopes of the LOWESS curve. $\mathrm{NA}$ - no match of ${ }^{87} \mathrm{Sr} /{ }^{86} \mathrm{Sr}$ with the LOWESS curve.

mixed-layers and their content in smectitic expandable layers is based on the method of Moore \& Reynolds (1997).

\section{Results}

\section{5.a. Sr-isotope ratios of oyster shell calcite}

The Sr-isotope data are graphically displayed in Figure 2 and summarized in Table 1. Measured Sr-isotope ratios of oyster calcite from the Água Doce Member of the Galé Formation at Guincho vary between 0.707373 \pm 0.000023 and $0.707456 \pm 0.000025(2 \sigma)$. The Srisotope record shows a distinct trend towards higher $\mathrm{Sr}$ ratios as a function of stratigraphic height. The lower part (22 $\mathrm{m}$ to $71 \mathrm{~m}$ ) is characterized by ${ }^{87} \mathrm{Sr} /{ }^{86} \mathrm{Sr}$ ratios fluctuating between $0.707379 \pm 0.000032$ and $0.707400 \pm 0.000021$ with the exception of two outliers in its upper part (samples L-41/1 and L-43/1). On average the middle part of the Água Doce Member (72-90 m) shows slightly higher ratios ranging between $0.707386 \pm 0.000025$ and $0.707413 \pm 0.000033$. The strata of the upper Água Doce Member (91 m to $128 \mathrm{~m}$ ) display the highest ratios with values between 0.707424 \pm 0.000021 and $0.707456 \pm 0.000025$ with the highest Sr-isotope ratio occurring in the uppermost sample measured (L-95, $121.2 \mathrm{~m})$.
Up to now, a number of similar late Early Cretaceous ${ }^{87} \mathrm{Sr} /{ }^{86} \mathrm{Sr}$ curves, both in terms of the trend and absolute values, have been published (Bralower et al. 1994; Jones et al. 1994; McArthur, Howarth \& Bailey, 2001). These curves show a distinct minimum in the Late Aptian followed by a subsequent rise towards higher ratios during Albian times. Following a steep increase during latest Aptian and Early Albian times, the curve starts to flatten out during the Middle Albian with the Late Albian being characterized by comparatively stable values reflecting a plateau phase of the seawater strontium trend. Our results obtained on oyster calcite appear to conform to such a pattern both in terms of trend and absolute values.

Converted to numerical ages according to the LOWESS best-fit curve (SIS Look-Up Table Version 4: 08 / 04; Howarth \& McArthur, 1997; McArthur, Howarth \& Bailey, 2001), ${ }^{87} \mathrm{Sr} /{ }^{86} \mathrm{Sr}$ ratios range from $109.4+1.4 /-4.7 \mathrm{Ma}(\mathrm{L}-11)$ to $108.3+1.4 /-4.7 \mathrm{Ma}$ (L-23), disregarding samples L41-1 and L43-1. This would indicate an Early to Middle Albian age based on the timescale of Gradstein, Ogg \& Smith (2004) for the lower part of the Água Doce Member. The middle part of this member is assigned to the Middle Albian $(109.1+1.2 /-4.2 \mathrm{Ma}(\mathrm{L}-32)$ to $107.0+2.7 /-13.2 \mathrm{Ma}$ (L-62)), whereas its uppermost interval would be Late Albian (104.2 to $103.4 \mathrm{Ma}$ with an error envelope ranging from c. 108.8 to $94.8 \mathrm{Ma}$ ) in age (Fig. 3). 


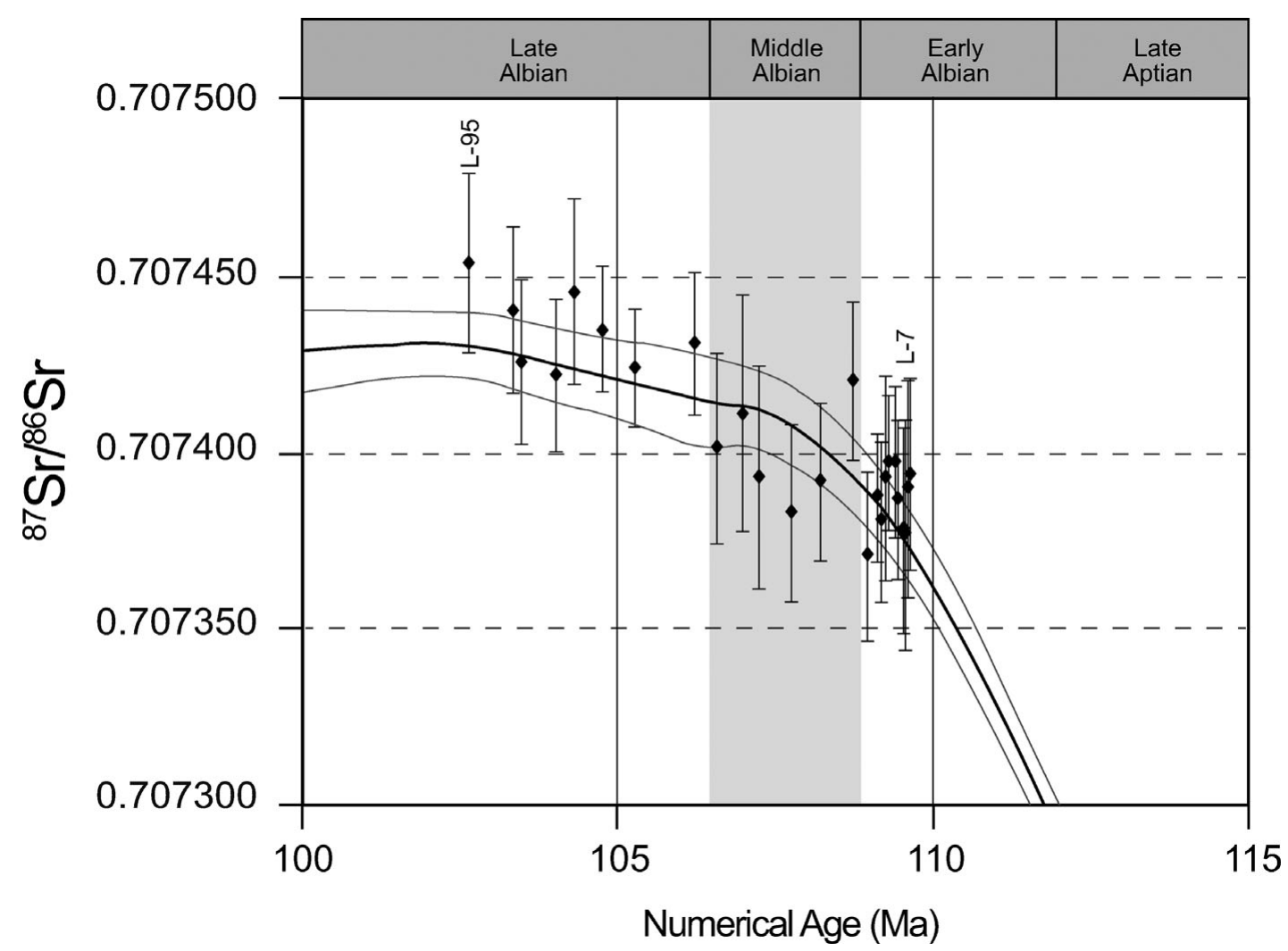

Figure 3. Comparison of LOWESS best-fit curve (black line) and $95 \%$ confidence intervals (thin grey lines) versus Sr-isotope ratios derived from the Guincho section. To reduce the effect of changes in sedimentation rate, the Guincho Sr-isotope record has been subdivided into three stratigraphic intervals (following the revised age assignment to Early, Middle and Late Albian in Fig. 2). The corresponding sets of data points derived from those three stratigraphic intervals have been plotted against numerical age.

However, owing to the flat gradient of the seawater Sr-isotope curve from the Middle Albian onwards, the error derived from the combined uncertainties of the measurements and of the SIS look-up table is considerable and results in significant uncertainties regarding the chronostratigraphic position of this part of the section (Table 1).

\section{5.b. Spore-pollen assemblage}

The sediments of the Guincho section contain a rich and diverse terrestrial palynoflora composed of various gymnosperm pollen, pteridophyte spores and angiosperm pollen taxa. Numerous spores and gymnosperm pollen were determined on the generic level; other forms were treated as groups (e.g. bisaccate pollen). In the studied record we differentiated 14 genera of gymnosperm pollen (including 7 species) and 20 genera of spores (including 14 species). Angiosperm pollen show a high diversity comprising 50 different forms, which have been previously described in detail by Heimhofer et al. (2007). To obtain information on changes in humidity, a xerophyte/hygrophyte ratio has been calculated following the concept of earlier studies (Visscher \& van der Zwan, 1981; Hochuli et al. 2010). In this study, all spores are regarded as hygrophytic plants whereas the xerophyte group is represented solely by Classopollis spp.
Based on quantitative distribution of the major pollen groups, four different local pollen zones (LPZ) are distinguished (Fig. 4) from the base to the top of the studied succession. The lowermost LPZ I (0$38.0 \mathrm{~m}$ ) is characterized by an increase in Classopollis spp. increasing from less than $5 \%$ to up to $44 \%$, high abundances of Inaperturopollenites spp. (up to $34 \%$ ) and a decline in Perinopollenites spp. (from $28 \%$ to less than $10 \%$ ) (Fig. $5 \mathrm{k}, \mathrm{m}-\mathrm{q}, \mathrm{s}, \mathrm{t}, \mathrm{x}$ ). Other gymnosperm pollen (including bisaccate pollen, Araucariacites spp., Exesipollenites spp.; Fig. 5a, b, $\mathrm{d}, \mathrm{j}, \mathrm{v}, \mathrm{w}, \mathrm{y})$ occur in low numbers, whereas trilete spore abundances vary between $4 \%$ and $17 \%$. In this interval, the majority of the spores belong to the spore taxa Cicatricosisporites spp., Deltoidospora spp. and Gleicheniidites spp. (Fig. 6a-c, e, f, r, w) and show a mean diversity of seven genera. Pollen assigned to Afropollis cf. jardinus are a rare but regular component of LPZ I where they account for up to $2 \%$ (Fig. 5aa, bb). Similarly, Sciadopityspollenites spp., Eucommiidites spp. and Callialasporites spp. occur as subordinate floral elements (Fig. 5c, e, f, h, $\mathrm{i}, \mathrm{r}, \mathrm{z}$ ). In LPZ I, angiosperm pollen are dominated by monocolpate forms and account for up to $8 \%$ (average $4.1 \%$ ). Tricolpate forms are restricted to rare occurrences of Tricolpites spp., Phimopollenites spp. and Retitricolpites spp.

LPZ II includes the interval between $38.0 \mathrm{~m}$ and $76.6 \mathrm{~m}$ and is characterized by a prominent peak 


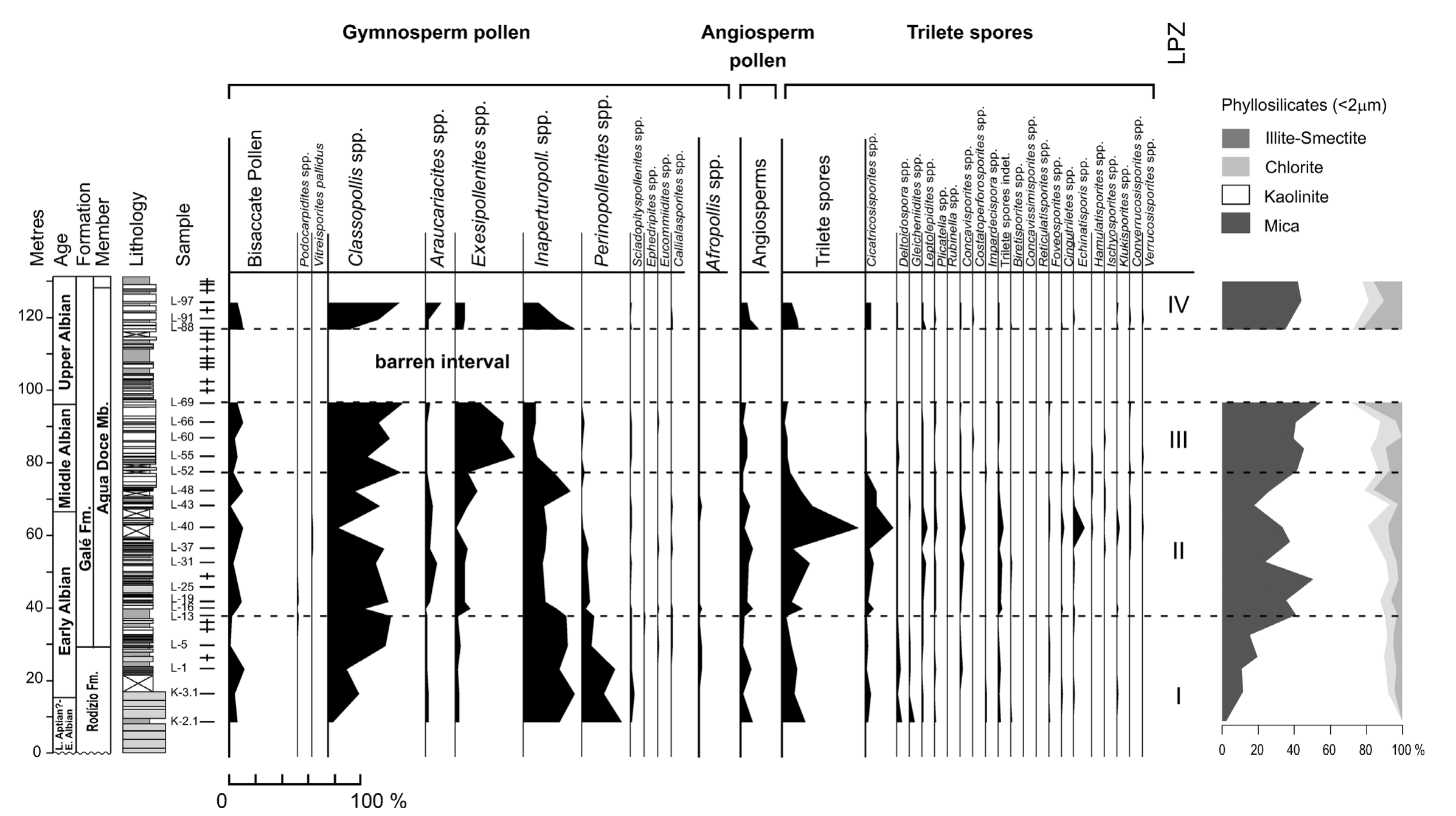

Figure 4. Simplified lithological log, lithostratigraphy, relative abundance [\%] of spores and pollen and clay mineral distribution through the Guincho section, Lusitanian Basin, Portugal. LPZ - local pollen zone. 

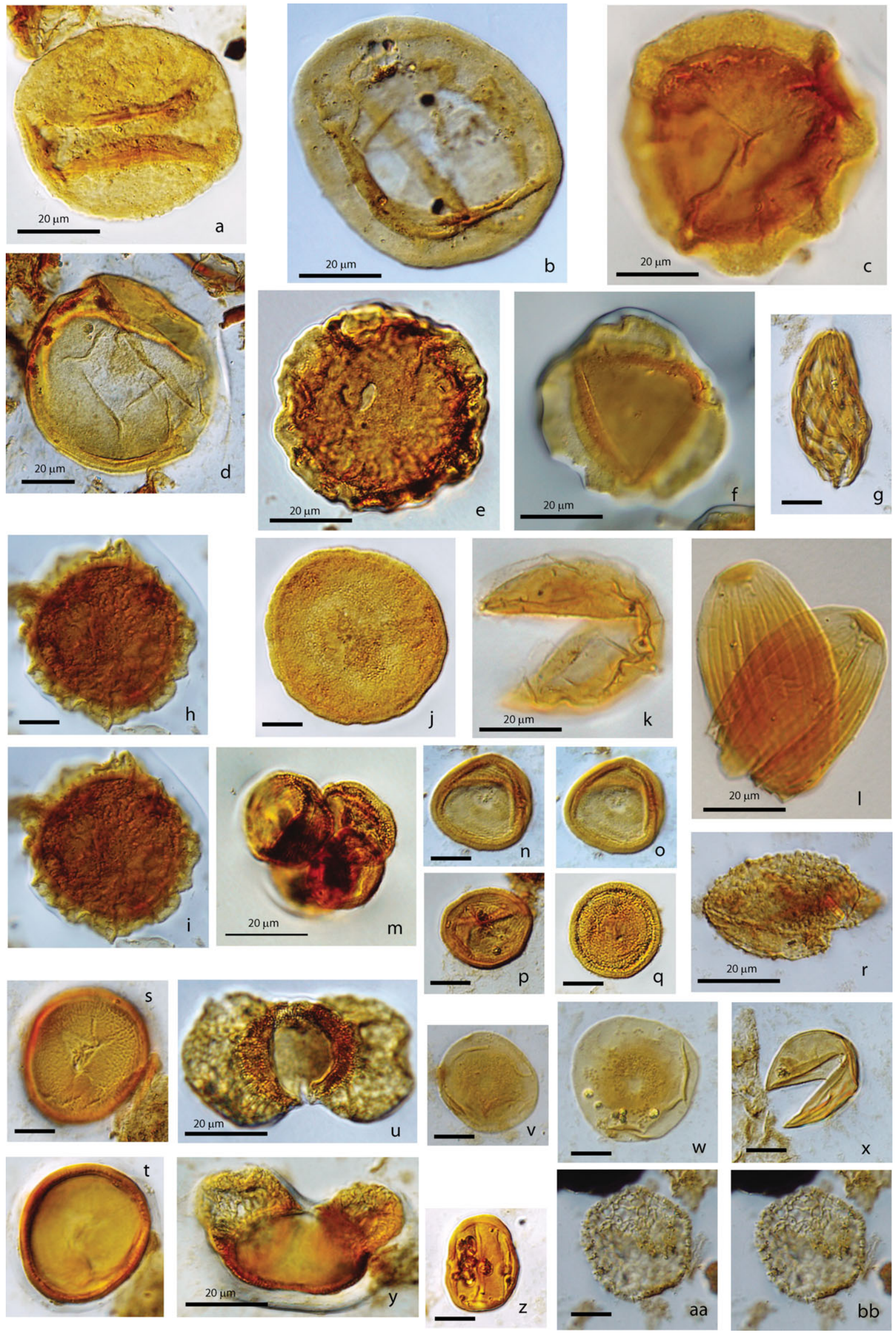

Figure 5. (Colour online) Photomicrographs of selected gymnosperm pollen grains from the Guincho section. Scale bar is $10 \mu \mathrm{m}$ if not indicated differently. (a) Araucariacites sp. (granulate form); L-72-5; 9.0/134.1; (b) Araucariacites cf. australis Cookson, 1947; L-72-5; 6.7/143.8; (c) Callialasporites sp.; L-91.5; 9.2/134.2; (d) Araucariacites australis Cookson, 1947; L-66-4; 12.1/145.5; 
in trilete spores reaching up to $54 \%$. This increase in spore abundance is most pronounced in the Cicatricosisporites group, but can also be observed in spores assigned to Plicatella spp., Leptolepidites spp., Concavisporites spp., Cingutriletes spp. and Echinatisporites spp. (Fig. 6d, g, h, m, z). Peak abundance of trilete spores is paralleled by the highest spore diversity with 13 different genera. The increase in spore abundance is accompanied by a significant decline in Classopollis spp., Exesipollenites spp., Inaperturopollenites spp. and a further decrease in Perinopollenites spp., whereas Araucariacites spp. displays a slight increase, reaching up to $8 \%$ of the sporomorph count. Exesipollenites spp. shows an increase at the beginning of LPZ II to values of up to $11 \%$, but decreases to less than $2 \%$ during peak spore abundance. Compared to LPZ I, bisaccate pollen show no significant variations in abundance and fluctuate between $2 \%$ and $11 \%$. Noteworthy is the occurrence of Podocarpidites spp. (Fig. 5u) and Vitreisporites pallidus within LPZ II. Angiosperm pollen represent a relatively common element within this interval (up to $8 \%$; average $4.9 \%$ ), and the first occurrence of several new tricolpate taxa is observed (including Artiopollis spp., Hammenia spp. and Striatopollis spp.)

The palynoflora of LPZ III (76.6-95.0 m) is characterized by low abundances of Inaperturopollenites spp., Araucariacites spp. and trilete spores, with the latter group showing a reduced mean diversity (average of 5.8 genera). In contrast, Classopollis spp. and Exesipollenites spp. show comparatively high abundances, the count of the latter reaching up to $42 \%$. Together with Sciadopityspollenites spp. and Eucommiidites spp., pollen assigned to Perinopollenites spp. are of subordinate importance and account for less than $2 \%$ of the assemblage. Ephedripites spp. (Fig. 5g) and Callialasporites spp are virtually absent. Compared to LPZ II the relative contribution of angiosperm pollen is slightly reduced within LPZ III and accounts for less than $5 \%$ (average $3.4 \%$ ).

Following a palynologically barren interval between $95.0 \mathrm{~m}$ and $115.2 \mathrm{~m}$, the assemblage characterizing the uppermost LPZ IV (115.2-127.8 m) shows an increase in Classopollis spp, which is paralleled by a decrease in Inaperturopollenites spp. In contrast to the previous LPZ, Exesipollenites spp. occurs in low abundances of less than $8 \%$, whereas trilete spores show a return to values of up to $12 \%$ (with Cicatricosisporites spp. accounting for $5 \%$ ). Perinopollenites spp. is virtually absent in this zone. Angiosperm pollen shows the highest relative abundance of the entire record reaching up to $12 \%$ (average $7.9 \%$ ).

\section{5.c. Clay mineral assemblage}

The clay mineral assemblage of the Guincho section (fraction $<2 \mu \mathrm{m}$ ) is dominated to varying degrees by mica and kaolinite whereas chlorite and I/S mixedlayer clay minerals represent only a subordinate fraction (Fig. 4). The relative proportion of the different clay minerals shows distinct variations within the stratigraphic succession. Mica accounts for $30.3 \%$ on average and shows a continuous increase throughout the succession ranging from less than $2.4 \%$ in the coarse-grained siliciclastic sediments of the Rodízio Formation to reach $>40 \%$ at the base of the Ponta da Galé Member. The increasing trend in mica abundance is punctuated by two peaks of $49.5 \%$ (at $47.7 \mathrm{~m}$ ) and $54.0 \%$ (at $95.0 \mathrm{~m}$ ), respectively. Compared to mica, kaolinite shows an opposite pattern with high kaolinite abundances $(>70 \%)$ prevailing within the Rodízio Formation and lower part of the Água Doce Member and reduced abundances $(\sim 40 \%)$ above, in most of the Água Doce Member (mean of $56.2 \%$ ). A distinct minimum of $18.0 \%$ is paralleled by peak mica abundances at $95.0 \mathrm{~m}$. Chlorite shows a relatively stable abundance pattern, fluctuating between $2.6 \%$ and $14.0 \%$ (mean of $6.3 \%$ ) in most samples (exception of $0 \%$ in the lowermost sample). In contrast, the $\mathrm{I} / \mathrm{S}$ mixed-layers show a slow but distinct increase in abundance from $0.0 \%$ at the very base to $24.5 \%$ in the uppermost interval (mean of $7.6 \%$ ). Following the criteria of Moore \& Reynolds (1997), identified I/S are of R1-R3 type with 15-20\% smectitic expandable layers.

The obtained results agree well with other studies on the clay assemblages of the Upper Aptian and Albian deposits of the region, showing a change from kaolinite to a predominance of illite approximately in Middle Albian times (Berthou, Blanc \& Chamley, 1982). Around 100 to $150 \mathrm{~km}$ further north in the basin, kaolinite is much more important all over the Figueira da Foz Formation (Upper Aptian to lower Cenomanian) (e.g. Grade \& Moura, 1992), with an increase in smectite and I/S mixed-layers in the presumably Upper Albian to lower Cenomanian levels (Rocha \& Gomes, 1995).

(e) Callialasporites dampieri (Balme) Sukh-Dev, 1961; L-16-3; 8.4/141.0; (f) Callialasporites trilobatus (Balme) Sukh Dev, 1961; L-72-5; 11.3/132.5; (g) Ephedripites cf. barghoornii/staplinii formgroup (Pocock) sensu Herngreen, 1973; L-16-4; 5.0/133.1; (h, i) Callialasporites aff. dampieri (Balme) Sukh-Dev, 1961; L-16-4; 9.2/121.7; (j) Araucariacites sp. (finely echinate form); L-55-5; 12.2/127.2; (k) Perinopollenites sp.; L-88.4; 8.0/135.0; (1) Steevesipollenites sp.; K-3.1.4; 19.7/142.0; (m) Classopollis sp. tetrade; L-55-5; 19.2/138.8; (n, o) Classopollis sp.; L-66-4; 7.0/134.3; (p) Classopollis sp.; L-55-5; 12.2/134.4; (q) Classopollis sp. (finely echinate form); L-55-5; 7.8/141.7; (r) Sciadopityspollenites sp.; L-16-4; 9.0/135.7; (s, t) Classopollis sp. (smooth form); L-66-4; 9.2/144.8; (u) Podocarpidites sp.; L-60-5; 10.3/127.4; (v) Exesipollenites sp.; L-66-4; 18.7/130.1; (w) Exesipollenites tumulus Balme, 1957; L-66-4; 7.2/144.2; (x) Inaperturopollenites sp.; L-66-4; 7.0/137.0; (y) Pinuspollenites sp.; L-66-4; 18.7/140.0; (z) Eucommiidites sp.; L-66-4; 13.2/130.3; (aa, bb) Afropollis cf. jardinus; (Brenner) Doyle, Jardiné \& Doerenkamp, 1982; L-16-4; 8.0/136.3. 

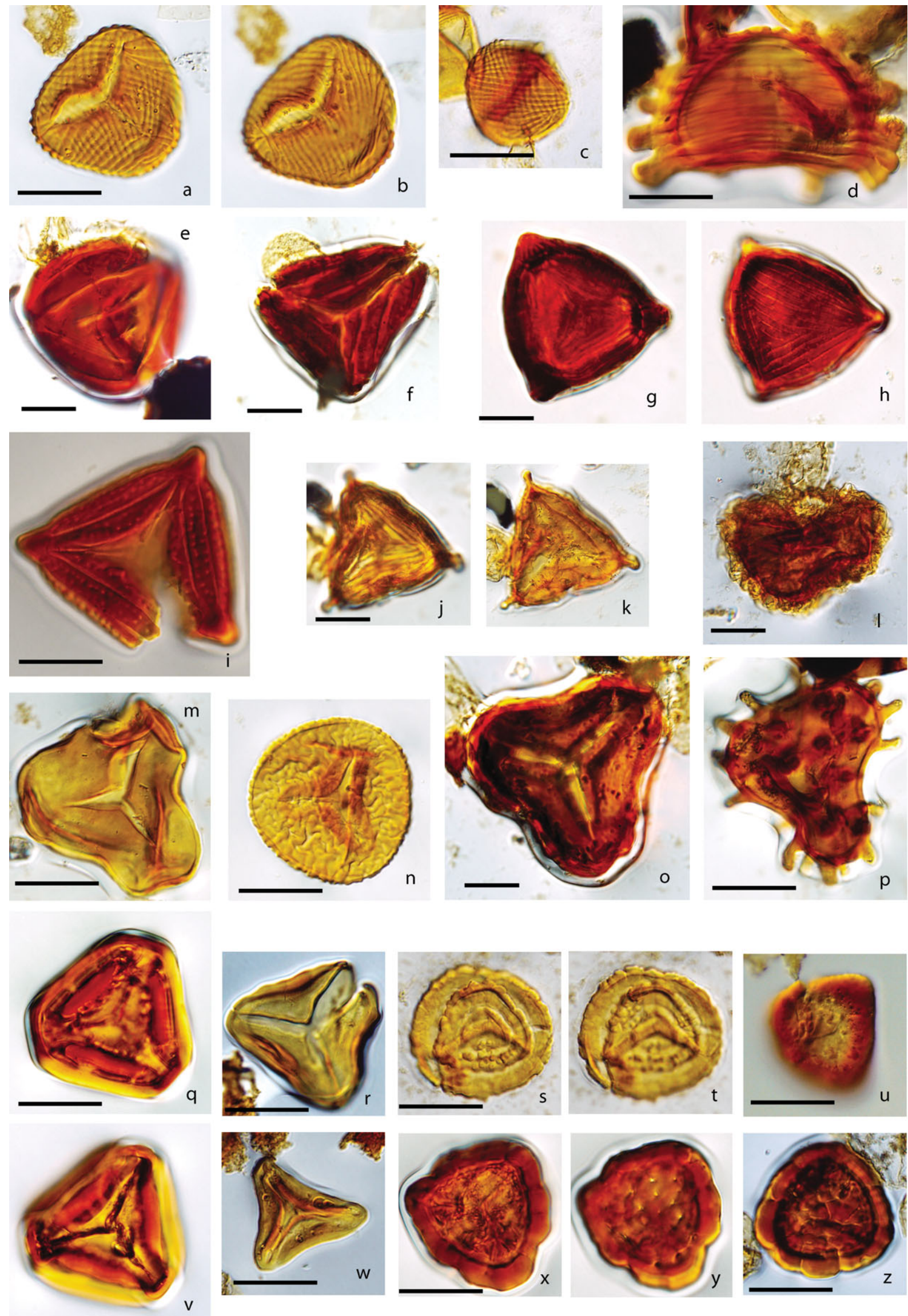

Figure 6. (Colour online) Photomicrographs of selected spores from the Guincho section. Scale bar is $20 \mu \mathrm{m}$ on all photomicrographs. (a, b) Cicatricosisporites cf. hallei Delcourt \& Sprumont, 1955; L-55-5; 16.1/134.7; (c) Cicatricosisporites cf. venustus Deák, 1963; L-66-4; 14.8/146.2; (d) Plicatella cf. cristata (Markova) Davies, 1985; L-52.6; 10.4/129.0; (e) Cicatricosisporites cf. patapscoensis Brenner, 1963; L-16-4; 12.3/122.2; (f) Cicatricosisporites sp.; L-16-3; 16.7/124.8; (g, h) Plicatella cf. concentrica (Kemp) Davies, 


\section{Discussion}

\section{6.a. Stratigraphic assignment}

Generally the ${ }^{87} \mathrm{Sr} /{ }^{86} \mathrm{Sr}$ ratios derived from low-Mg oyster calcite of the studied Guincho section match the global marine Sr-isotope trend for the Albian Stage, both in terms of the general rise in the ratio and the absolute values (McArthur, Howarth \& Bailey, 2001). Correlation with existing Sr-isotope curves from open marine environments (Bralower et al. 1997) allows a tentative distinction between Lower, Middle and Upper Albian strata. Comparison with oyster-derived Sr-isotope results from the Portuguese Algarve region generated by the same analytical technique (Burla et al. 2009) shows a good match between the two records for the Early to Middle Albian interval, enabling correlation between the two successions. On the other hand, certain discrepancies are observed between the Guincho results and an oyster-derived Sr-isotope record from the Albian of northern Texas, USA (Denison et al. 2003). Both records show a distinct increase in ${ }^{87} \mathrm{Sr} /{ }^{86} \mathrm{Sr}$ ratios for the Early to Middle Albian interval, but both amplitudes and absolute values differ significantly. The steeper gradient and the significantly higher ${ }^{87} \mathrm{Sr} /{ }^{86} \mathrm{Sr}$ ratios (reaching up to 0.70750) of the Texan oyster record may reflect freshwater influx, which could have shifted the original seawater $\mathrm{Sr}$-isotope composition to more radiogenic ratios (Ingram \& Sloan, 1992; Korte et al. 2003). A similar mechanism may be invoked to explain the small-scale shifts observed in the Guincho Sr-isotope record, in particular in its lower part. Here, the observed gradual low-amplitude fluctuations may reflect variations in the riverine input of radiogenic $\mathrm{Sr}$ derived from continental silicate weathering.

Generally the age assignment based on the isotope record of the Guincho section is in good agreement with existing age interpretations, thus confirming the accuracy of previous stratigraphic studies based on macrofauna and orbitolinids (Rey, Bilotte \& Peybernes, 1977; Berthou \& Schroeder, 1979), dinoflagellate cysts (Berthou \& Leereveld, 1990; Heimhofer et al. 2007) and sequence-stratigraphic considerations (Rey, 1992; Dinis, Rey \& de Graciansky, 2002; Rey, de Graciansky $\&$ Jacquin, 2003). A late Early Albian age for the lower part of the Água Doce Member is corroborated by the consistent occurrence of Dinopterygium cladoides.

A distinct offset in the Sr-isotope record in the middle part of the Água Doce Member at $\sim 95 \mathrm{~m}$ (between samples L-66 and L-69/1) may reflect a sedimentary hiatus. Evidence is provided by the occurrence of a distinct hardground (discontinuités sedimentaires in
Rey, 1992), which is considered to reflect the maximum flooding surface of a second-order cycle (Dinis, Rey \& de Graciansky, 2002; Rey, de Graciansky \& Jacquin, 2003).

Stratigraphic discrepancies exist with regard to the position of the upper part of the Água Doce Member and the lowermost part of the Ponta da Galé Member ( 100-131 m; Fig. 2). According to the numerical age assignment derived from the Sr-isotope data, this interval belongs to the early Late Albian (c. 104.2 to 103.4 Ma nominal; however, note the error envelope allows for a range of $c$. 108.8 to $94.8 \mathrm{Ma}$ ). Similarly, Rey, Bilotte \& Peybernes (1977) considered the interval above the bed including the ammonite Knemiceras uhligi $(\sim 95 \mathrm{~m})$ to be Late Albian in age, and Berthou \& Schroeder (1979) indicate an Early to Middle Albian age for the carbonates below $\sim 85 \mathrm{~m}$ based on the occurrence of the orbitolinid Simplorbitolina manasiconulus. In contrast, a Middle Albian age has been proposed for the interval above $\sim 92 \mathrm{~m}$ based on the absence of a characteristic Late Albian dinoflagellate cyst assemblage (Heimhofer et al. 2007). However, given the near-shore character of the deposits in this part of the succession, the lack of typical Late Albian dinoflagellate taxa may result from the proximity and restricted character of the depositional setting.

In summary, considering the biostratigraphic constraints and the ${ }^{87} \mathrm{Sr} /{ }^{86} \mathrm{Sr}$ chronostratigraphic best-fit, the boundary between the Middle and Late Albian is tentatively located in the studied section between $89.9 \mathrm{~m}$ (sample L-66) and $95.0 \mathrm{~m}$ (sample L-69). The Sr-isotope results of the Guincho section further support the suitability of oyster-derived low-Mg calcite for stratigraphic applications and corroborate earlier biostratigraphic studies.

\section{6.b. Significance of near-shore marine palynomorph records}

When dealing with sporomorph assemblages obtained from near-shore marine sedimentary deposits, potential effects of hydrodynamic sorting during transportation and deposition have to be considered. Differential sorting due to varying buoyancy or sporomorph size and density can results in significant bias of the studied association (Tyson, 1995; Traverse, 2007). This applies in particular to bisaccate conifer pollen grains, which can remain afloat for weeks explaining the observed relative off-shore increase in bisaccate pollen in modern continental margin sediments (Heusser \& Balsam, 1977). In the studied succession the relative abundance

1985; L-16-3; 6.4/140.3; (i) Costatoperforosporites triangulatus Deák, 1962; L-55.5; 13.5/128.0; (j, k) Appendicisporites potomacensis Brenner, 1963; L-16-3; 12.2/123.7; (1) Crybelosporites cf. pannuceus (Brenner) Srivastava, 1977; L-16-3; 18.4/131.2; (m) Concavisporites sp.; L-16-4; 8.2/124.9; (n) Hamulatisporites sp.; L-55-5; 18.9/132.6; (o) Impardecispora sp.; L-16-4; 8.3/126.3; (p) Trilobosporites apibaculatus Brenner, 1963; L-16-3; 9.6/131.8; (q, v) Matonisporites excavatus Brenner, 1963; L-55-5; 7.9/141.5; (r) Gleicheniidites cf. senonicus Ross, 1949; L-60-5; 17.8/136.3; (s, t) Taurocusporites cf. segmentatus Stover, 1962; L-66-4; 16.2/146.3; (u) Cingutriletes cf. congruens Pierce, 1961; L-88.4; 8.8/131.8; (w) Gleicheniidites cf. circinidites (Cookson) Brenner, 1963; L-55-5; 14.8/137.0; (x, y) Klukisporites sp.; L-55-5; 9.0/133.0; (z) Leptolepidites sp.; L-55-5; 12.2/129.2. 
of bisaccate pollen varies between $2 \%$ and $12 \%$, but does not show significant fluctuations with stratigraphic height. In fact, during Albian times sedimentation in the Lusitanian Basin was affected by distinct sea-level variations (Dinis, Rey \& de Graciansky, 2002; Rey, de Graciansky \& Jacquin, 2003) as indicated by changes from peritidal (estuary to upper delta) to inner and shallow platform depositional settings (Rey \& Cugny, 1978). However, the relatively stable distribution of bisaccates does not show a clear sporomorph sorting due to varying distance from the shoreline. Bias of the quantitative composition of sporomorph assemblages due to differential sorting has also been observed between thin-walled, non-saccate pollen grains and dense, ornamented trilete spores, with the latter being preferentially deposited more proximally, often in the vicinity of a river mouth (Heusser \& Balsam, 1977; Tyson, 1995). Again, the Guincho record does not display a strong correspondence between trilete spore abundance and sea-level variations since the exceptionally high spore abundances in LPZ II occur during a long-lasting transgressive phase, even if the minimum in LPZ III coincides with the second-order highest sea-level. The deposits in LPZ II show no sign of enhanced riverine detrital input or sea-level lowering, which could explain the pronounced peak in spore percentages. Hence the effects of hydrodynamic sorting processes are considered to be of minor importance for most of the observed sporomorph distribution patterns. This assumption is in agreement with the view that sporomorph assemblages obtained from marginal marine settings reflect changes in vegetation patterns on the adjacent hinterland rather than sorting during transport and deposition (Tyson, 1995; Abbink, 1998; Traverse, 2007).

\section{6.c. Evolution of vegetation patterns and climate}

The composition of the sporomorph assemblages obtained from the Albian deposits of the Guincho section is in good accordance with existing sporomorph records from other parts of Iberia (Groot \& Groot, 1962; Medus \& Berthou, 1980; Medus, 1982; TaugourdeauLantz et al. 1982; Solé da Porta et al. 1994; Peyrot et al. 2007; Diéguez, Peyrot \& Barrón, 2010; VillanuevaAmadoz et al. 2010). The composition fits well into the palaeophytogeographic scheme of Brenner (1976) in which the occurrence of various types of coniferderived gymnosperm pollen (e.g. Classopollis spp., Araucariacites spp., Inaperturopollenites spp. and of bisaccate pollen grains of pinacean affinity) and the occurrence of diverse pteridophyte spore associations (including numerous representatives of the Schizaeaceae and Gleicheniaceae) place the Guincho record into the Southern Laurasian floral province. However, minor influence of the Northern Gondwana province adjacent to the south is indicated by the continuous occurrence of typical Gondwanan floral elements including Afropollis spp. as well as by the regular occurrence of pollen grains of the Ephedripites group.
A position at the southernmost margin of the Southern Laurasian floral province is in good agreement with the concept of a transitional zone between the two major floral provinces, which incorporates floral elements from both provinces to varying extent (Hochuli, 1981).

Based on the presumed ecological preferences and habitat requirements of the parent plants of the observed sporomorph groups, the distribution patterns can be interpreted in terms of changes in palaeovegetation and corresponding environmental conditions. Abbink (1998) and Abbink, Van KonijnenburgVan Cittert \& Visscher (2004) provide a comprehensive compilation of presumed ecologies of the parent plants of Late Jurassic-earliest Cretaceous sporomorph groups, which serves as a basis for the interpretation of the Guincho record. A distinct shift from forest communities dominated by cupressacean and taxodiacean conifers to the dominance of Classopollis(Cheirolepidaceae) is observed in LPZ I (late Early Albian). Conifers of the family Cheirolepidaceae are considered thermophilous and drought-resistant and have thrived in a wide range of habitats, ranging from well-drained upland to coastal lowlands to even saline habitats (Vakhrameyev, 1982; Watson, 1988; Heimhofer et al. 2008; Mendes et al. 2010). In contrast, Taxodiacean conifers (as indicated by Perinopollenites) are interpreted to form part of lush vegetation thriving predominantly in wet lowland environments (Pelzer, Riegel \& Wilde, 1992). Hence, the marked increase in cheirolepidacean at the expense of taxodiacean conifers during LPZ I most probably reflects a shift towards more arid conditions in the hinterland of the Lusitanian Basin. This climatic trend is supported by the clay mineral assemblage, where a decline in kaolinite abundance can be observed. Formation of kaolinite is usually associated with intense chemical weathering under humid tropical to subtropical conditions (Gaucher, 1981; Chamley, 1989). An inverse trend back towards a more humid climate characterizes the late Early Albian to early Middle Albian interval of LPZ II. Here, a pronounced peak in pteridophytes, particularly of ferns of the families Schizaeaceae and Matoniaceae as well as lycopsids, is accompanied by a marked decrease in cheirolepidacean conifers and points to the establishment of more humid conditions. High abundances of pteridophytes are characteristic of relatively moist and lush vegetation occurring, for example, along riversides and/or in costal lowlands (Van Konijnenburg-Van Cittert \& Van der Burgh, 1989; Pelzer, Riegel \& Wilde, 1992; Abbink, 1998). Peak abundances in pteridophytes are accompanied by Vitreisporites-producing pteridosperms, which are typically associated with warm and rather wet habitats (Pelzer, 1984; Van Konijnenburg-Van Cittert \& Van der Burgh, 1989). A trend towards a more humid climate may be interpreted from a subtle increase in kaolinite content and decreasing mica abundances, reflecting a shift from physical to predominantly chemical weathering processes. Following this period of comparatively humid conditions, a reverse trend 
towards a more arid climate is indicated in LPZ III by a pronounced increase of Exesipollenites spp., most probably produced by bennettitalean or cupressacean plants. According to Watson \& Sincock (1992) and Hotton \& Baghai-Riding (2010) the parent plants of Exesipollenites preferred a dry microclimate and were able to withstand a certain saline influence. This climatic interpretation is supported by sedimentological evidence. Reduced riverine siliciclastic input to the basin is indicated by the predominance of carbonaterich deposits during LPZ III. Similarly, decreasing percentages of kaolinite point to a reduction in chemical weathering rates, most probably owing to limited water availability. A slightly modified picture emerges from the Late Albian interval of LPZ IV, where moderate abundances of pteridophytes occur in association with cupressacean, araucariacean and taxodiacean conifers and angiosperms. A rise in Classopollis pollen may indicate increasing dominance of drought-adapted cheirolepidaceans. Increased abundances of I/S mixedlayer minerals point to the erosion of poorly drained soils in the hinterland (Deconinck \& Chamley, 1995). The climatic condition prevailing during LPZ IV are probably best described as semi-arid, reflecting conditions in between the enhanced aridity of LPZ III and the humid phase of LPZ II.

\section{6.d. Palaeoenvironmental implications}

Evaluation of the palynological data indicates that during Early to Middle Albian times the hinterland of the southern Lusitanian Basin was covered by evergreen vegetation, adapted to semi-humid conditions. Mixed conifer forests, essentially composed of Cheirolepidaceae, Taxodiaceae-Cupressaceae and Araucariaceae, sometimes accompanied by different types of Podocarpaceae and Pinaceae, prevailed. The forest understorey was composed of ferns of the groups Schizaeaceae, Gleicheniaceae and Cyatheaceae/Dicksoniaceae/Dipteridaceae and as well as of lycopsids and early angiosperms. Similar floral assemblages have been described from the Albian of Iberia, from the Basque-Cantabrian basin (Barrón, Comas-Rengifo \& Elorza, 2001) and from the Oliete Sub-basin (Peyrot et al. 2007).

However, the stratigraphic succession of the palynofloras reflect some marked changes in the plant communities, including the demise of taxodiacean conifers (LPZ I), a pronounced increase in pteridophyte spores, particularly of Schizaeaceae (LPZ II) and a rise in Cupressaceae (LPZ III) as well as an overall increase in angiosperm pollen throughout the studied section. Whereas the increase in the abundance of angiosperm pollen is interpreted to reflect the incipient radiation of this group during Albian times (Medus \& Berthou, 1980; Heimhofer et al. 2005, 2007) observed variations in the distribution of gymnosperm pollen and pteridophyte spores are best explained as a response of vegetation to changes in regional climatic conditions, in particular to moisture availability. Changes in humidity during the studied time interval are well expressed in the xerophyte/hygrophyte ratio (Fig. 7). The dataset indicates significant variations in the temporal distribution of moisture availability, with an increase in regional humidity during late Early Albian times. Coeval deposits from the Algarve Basin, located $\sim 200 \mathrm{~km}$ towards the south, show no evidence for increased humidity, neither in the palynoflora nor in the clay mineral composition (Heimhofer et al. 2008). Here, the palynological assemblages are strongly dominated by Classopollis pollen, resulting in a constantly high xerophyte/hygrophyte ratio throughout the Early Albian interval (Fig. 7).

Late Aptian to early Cenomanian deposits in the northern part of the western Iberian margin include very high proportions of kaolinite and are interpreted as a braided fluvial system (Dinis et al. 2008), pointing to a climate that was, at least seasonally, wet. In contrast, sedimentological evidence for relatively arid conditions prevailing in eastern Iberia during Albian times is derived from the presence of a subtropical ergmargin system (Rodríguez-López et al. 2008, 2010). Sand sea development resulted from a northward shift of the northern subtropical high-pressure system, probably linked to the opening of the equatorial Atlantic gateway (Poulsen, Gendaszek \& Jacob, 2003). Arid palaeoclimatic conditions prevailing in southern and eastern Iberia during latest Early Cretaceous times are in line with the palaeogeographic reconstructions of Chumakov et al. (1995). According to these authors, the boundary between the so-called Northern Hot Arid belt and the Northern Mid-latitude Warm humid belt divides the Iberian Peninsula in an E-W direction. The position of the studied Guincho section close to the boundary of the two belts made this area sensitive to climatic changes resulting in expansion or contraction of the latitudinally arranged climatic zones. Hence, the occurrence of a more hygrophilous vegetation during late Early Albian times may reflect a transient expansion of the Northern Mid-latitude Warm humid belt towards the south, probably driven by the rearrangement of atmospheric or oceanic heat transport.

\section{Conclusions}

(1) The near-shore marine deposits of the Guincho section of the Lusitanian Basin, W Portugal were deposited in Early to early Late Albian times as indicated by Sr-isotope data derived from low-Mg oyster calcite. The new Sr-isotope record corroborates the existing biostratigraphic assignment of the lower Água Doce Member as being Early to Middle Albian in age. However, high ${ }^{87} \mathrm{Sr} /{ }^{86} \mathrm{Sr}$ values between $0.707424 \pm$ 0.00002 and $0.707456 \pm 0.00003$ characterizing the uppermost Água Doce Member, point to an age not older than early Late Albian. The Sr-isotope data obtained using laser-ablation multi-collector ICP-MS highlight the suitability of low-Mg oyster shell calcite 


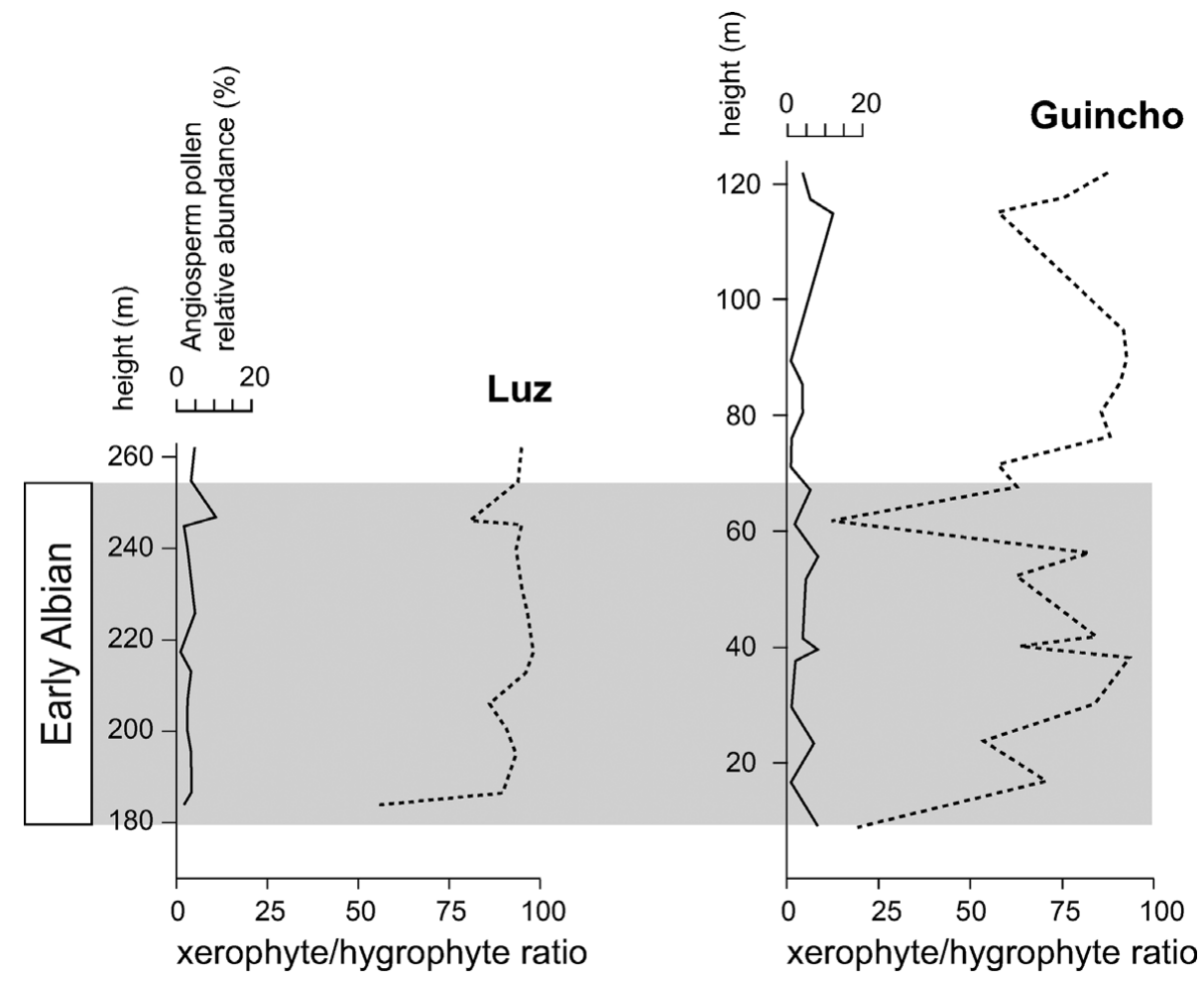

Figure 7. Comparison of the xerophyte/hygrophyte ratios (dashed line) and angiosperm pollen relative abundances (solid line) between the Early Albian records of Guincho (Lusitanian Basin, W Portugal) and the Luz (Algarve Basin, S Portugal). Xerophyte/hygrophyte ratio of the Luz record is based on Heimhofer et al. (2008), angiosperm pollen abundance is based on Heimhofer et al. (2007), and stratigraphic assignment follows Burla et al. (2009).

for the age assignment of Cretaceous near-shore marine deposits.

(2) The sedimentary deposits are characterized by a rich and diverse palynoflora essentially composed of conifer-derived gymnosperm pollen, trilete pteridophyte spores and angiosperm pollen. According to the spore-pollen data, the hinterland of the Lusitanian Basin was covered by an evergreen vegetation composed of mixed conifer forests (including Cheirolepidaceae, Taxodiaceae-Cupressaceae, Araucariaceae and subordinately Podocarpaceae, Pinaceae) with the understorey being composed of various ferns (Schizaeaceae, Gleicheniaceae, Cyatheaceae, Dicksoniaceae, Dipteridaceae), and a relatively diverse angiosperm assemblage. This vegetation is interpreted to correspond to semi-humid conditions.

(3) Across the stratigraphic succession, the sporepollen record shows some distinct fluctuations in assemblage composition. Similarly, the clay mineral assemblages vary with stratigraphic height. Important changes in the plant community structure include the demise of taxodiacean conifers (LPZ I), a pronounced increase in pteridophyte spores (LPZ II) and a rise in bennettitalean or cupressacean-derived pollen (Exesipollenites spp.; LPZ III). In concert with the clay mineral data, these changes in the distribution patterns of gymnosperm pollen and pteridophyte spores are interpreted as reflecting changes in regional climate patterns, particularly in moisture availability. Distinct differences in the xerophyte/hygrophyte ratio between the Guincho record and data from the southern Algarve
Basin are interpreted as reflecting the position of gross climatic belts, with southern and southeastern Iberia being under the influence of the northern subtropical high-pressure system during Early Albian times.

Acknowledgements. We thank P. W. Skelton (Open University Milton Keynes) for field assistance, U. Wiechert (FU Berlin) and the technical staff of the Institute of Isotope Geochemistry and Mineral Resources for support with the Srisotope measurements. The thorough comments of the editor and two anonymous reviewers are gratefully acknowledged. Financial support from ETH-Project TH-34/99-4 and by the Nordrhein-Westfälische Akademie der Wissenschaften und Künste to UH is gratefully acknowledged. JD's participation is supported by FCT (Fundação para a Ciência e a Tecnologia) through projects PTDC/CTE-GIX/104999/2008 and PTDC/CTE-GIX/113983/2009, with co-participation of the COMPETE Program/FEDER European Fund.

\section{References}

ABBINK, O. A. 1998. Palynological Investigations in the Jurassic of the North Sea region. Ph.D. thesis, Universiteit Utrecht, The Netherlands, 192 pp. Published thesis.

AbBink, O. A., VAn KoniJnenburG-VAn CitTert, J. H. A \& VISSCHER, H. 2004. A sporomorph ecogroup model for the Northwest European Jurassic-Lower Cretaceous: concepts and framework. Geologie en Mijnbouw 83, 1731.

AdATte, T., Stinnesbeck, W. \& Keller, G. 1996. Lithostratigraphic and mineralogic correlations of near $\mathrm{K} / \mathrm{T}$ boundary clastic sediments in northeastern Mexico: implications for origin and nature of deposition. In The Cretaceous-Tertiary Event and Other Catastrophes 
in Earth History (eds G. Ryder, D. E. Fastovsky \& S. Gartner), 211-26. Geological Society of America, Special Paper no. 307.

Balme, B. E. 1957. Spores and Pollen Grains From the Mesozoic of Western Australia. Commonwealth Scientific and Industrial Resarch Organisation, Australia, Coal Research Section, Reference T.C. 25, 48 pp.

Barrón, E., Comas-Rengifo, M. J. \& Elorza, I. 2001. Contribuciones al estudio palinológico del Cretácico Inferior de la Cuenca Vasco-Cantábrica: los afloramientos ambarígenos de Peñacerrada (España). Coloquios de Paleontología 52, 135-56.

Berthou, P. Y., Blanc, P. \& Chamley, H. 1982. Sédimentation argileuse comparée au Crétacé moyen et supérieur dans le bassin occidental portugais et sur la marge voisine (site 398 DSDP): enseignements paléogéographiques et tectoniques. Bulletin de la Société géologique de France 24, 461-72.

Berthou, P.-Y. \& LeEREVELD, H. 1990. Stratigraphic implications of palynological studies on Berriasian to Albian deposits from western and southern Portugal. Review of Palaeobotany and Palynology 66, 313-44.

Berthou, P. Y. \& Schroeder, R. 1979. Découverte d'un niveau à Simplorbitolina CIRY et RAT dans l'Albien de Guincho (région de Lisbonne, Portugal). Comptes Rendus Hebdomadaires des Séances de l'Académie des Sciences, Serie D: Sciences Naturelles 288, 591-4.

Bice, K. L., Birgel, D., Meyers, P. A., Dahl, K. A., HINRICHS, K.-U. \& NoRRIS, R. D. 2006. A multiple proxy and model study of Cretaceous upper ocean temperatures and atmospheric $\mathrm{CO}_{2}$ concentrations. Paleoceanography 21, PA2002, doi:10.1029/ 2005PA001203, $17 \mathrm{pp}$.

Bralower, T. J., ARThur, M. A., LeCKie, R. M., Sliter, W. V., AlLARD, D. J. \& SCHLANGER, S. O. 1994. Timing and paleoceanography of oceanic dysoxia/anoxia in the Late Barremian to Early Aptian (Early Cretaceous). Palaios 9, 335-69.

Bralower, T. J., Fullagar, P. D., Paull, C. K., Dwyer, G. S. \& LECKIE, R. M. 1997. Mid-Cretaceous strontiumisotope stratigraphy of deep-sea sections. Geological Society of America Bulletin 109, 1421-42.

Brenner, G. J. 1963. The Spores and Pollen of the Potomac Group of Maryland. Maryland Department of Geology, Mines and Water Resources Bulletin no. 27, 215 pp.

BrenNER, G. 1976. Middle Cretaceous floral provinces and early migrations of angiosperms. In Origin and Early Evolution of Angiosperms (ed. C. B. Beck), pp. 23-44. New York: Columbia University Press.

Burla, S., Oberli, F., Heimhofer, U., Wiechert, U. \& WeISSERT, H. 2009. Improved time control on Cretaceous coastal deposits: new results from $\mathrm{Sr}$ isotope measurements using laser ablation. Terra Nova 21, 401-9.

CARTER, J. G. 1990. Shell microstructural data for the Bivalvia. Part IV. Order Ostreoida. In Skeletal Biomineralization: Patterns, Processes and Evolutionary Trends (ed. J. Carter), pp. 347-62. New York: Van Nostrand Reinhold.

Chamley, H. 1989. Clay Mineralogy. Berlin: Springer, 623 pp.

Christensen, J. N., Halliday, A. N., Lee, D.-C. \& Hall, C. M. 1995. In situ Sr isotopic analysis by laser ablation. Earth and Planetary Science Letters 136, 79-85.

Chumakov, N. M., Zharkov, M. A., Herman, A. B., Doludenko, M. P., Kalandadze, N. M., LebedeV, E. L., Ponomarenko, A. G. \& Rautian, A. S. 1995.
Climatic belts of the mid-Cretaceous time. Stratigraphy and Geological Correlation 3, 241-60.

Clarke, L. J. \& JenKyns, H. C. 1999. New oxygen isotope evidence for long-term Cretaceous climate change in the Southern Hemisphere. Geology 27, 699-702.

Coiffard, C., Gomez, B. \& Thevenard, F. 2007. Early Cretaceous angiosperm invasion of western Europe and major environmental changes. Annals of Botany 100, 545-53.

Cookson, I. C. 1947. Plant microfossils from the lignites of Kerguelen Archipelago. British and New Zealand Antarctic Research Expedition, 1929-1931, Reports, series A 2, 127-42.

Crane, P. R., Frits, E. M. \& Pedersen, K. R. 1995. The origin and early diversification of angiosperms. Nature 374, 27-33.

CRANe, P. R. \& LidgaRd, S. 1989. Angiosperm diversification and paleolatitudinal gradients in Cretaceous floristic diversity. Science 246, 675-8.

DAVIES, E. H. 1985. The Anemiacean, Schizaeacean and related spores: an index to genera and species. Canadian Technical Report of Hydrography and Ocean Sciences 67. Bedford Institute of Oceanography.

DEÁK, M. H. 1962. Két új spóra gensuz az apti agyag márga sorozatbol. Földtani Közlöny 92, 230-5.

DEÁK, M. H. 1963. Quelques spores striées de l'étage Aptien. Revue de Micropaléontologie 5, 251-6.

DECONINCK, J.-F. \& CHAMLEY, B. 1995. Diversity of smectite origins in Late Cretaceous sediments: examples of chalks from northern France. Clay Minerals 30, 36579.

Delcourt, A. F. \& Sprumont, G. 1955. Les spores et grains de pollen du Wealdien du Hainaut. Mémories de la Société Belge de Géologie, de Paléontologie et d'Hydrologie, Nouvelle Série 5, 1-73.

Denison, R. E., Miller, N. R., Scott, R. W. \& Reaser, D. F. 2003. Strontium isotope stratigraphy of the Comanchean Series in north Texas and southern Oklahoma. Geological Society of America Bulletin 115, 669-82.

Diéguez, C., PEYrot, D. \& BARRóN, E. 2010. Floristic and vegetational changes in the Iberian Peninsula during Jurassic and Cretaceous. Review of Palaeobotany and Palynology 162, 325-40.

Dinis, J. L., ReY, J., Cunha, P. P., CAllapez, P. \& PENA dos REIS, R. 2008. Stratigraphy and allogenic controls of the western Portugal Cretaceous: an updated synthesis. Cretaceous Research 29, 772-80.

Dinis, J. L., ReY, J. \& DE GRaCiansky, P. C. 2002. The Lusitanian Basin (Portugal) during the late AptianAlbian: sequential arrangement, proposal of correlations, evolution. Comptes Rendus Geoscience 334, 75764.

DinIS, J. L. \& TRINCÃO, P. 1995. Recognition and stratigraphical significance of the Aptian unconformity in the Lusitanian Basin, Portugal. Cretaceous Research 16, 171-86.

Doyle, J. A., JARdiné, S. \& Doerenkamp, A. 1982. Afropollis, a new genus of early angiosperm pollen, with notes on the Cretaceous palynostratigraphy and palaeoenvironments of northern Gondwana. Bulletin des Centres de Recherches Exploration-Production ElfAquitaine 6, 39-117.

Doyle, J. A. \& RobBINS, E. I. 1977. Angiosperm pollen zonation of the continental Cretaceous of the Atlantic Coastal Plain and its application to deep wells in the Salisbury Embayment. Palynology 1, 43-78.

Erbacher, J., Friedrich, O., Wilson, P. A., LehMANN, J. \& WeISS, W. 2011. Short-term warming events 
during the boreal Albian (mid-Cretaceous). Geology 39, 223-6.

Erbacher, J., Huber, B. T., Norris, R. D. \& MArkey, M. 2001. Increased thermohaline stratification as a possible cause for an ocean anoxic event in the Cretaceous period. Nature 409, 325-7.

ERbacher, J., Thurow, J. \& LitTKe, R. 1996. Evolution patterns of radiolaria and organic matter variations: a new approach to identify sea-level changes in MidCretaceous pelagic environments. Geology 24, 499-502.

Feild, T. S., Chatelet, D. S. \& BrodribB, T. J. 2009. Ancestral xerophobia: a hypothesis on the whole plant ecophysiology of early angiosperms. Geobiology 7, 237-64.

Forster, A., Schouten, S., BaAs, M. \& Sinninghe DAMSTÉ, J. 2007. Mid-Cretaceous (Albian-Santonian) sea surface temperature record of the tropical Atlantic Ocean. Geology 35, 919-22.

Frits, E. M., Pedersen, K. R. \& Crane, P. R. 2010. Cretaceous diversification of angiosperms in the western part of the Iberian Peninsula. Review of Palaeobotany and Palynology 162, 341-61.

GAUCHER, G. 1981. Les Facteurs de la Pédogenèse. Brussels, Belgium: Dison, $730 \mathrm{pp}$.

Grade, J. \& MourA, A. C. 1992. Estudo das formações gresosas cretácicas (Aptiano-Albiano) do flanco sul do anticlinal de Alpedriz-Porto Carro. Estudos, Notas e Trabalhos da Direcção Geral de Geologia e Minas 34, 85-94.

Gradstein, F. M., OgG, J. G. \& Smith, A. G. 2004. A Geologic Time Scale 2004. Cambridge: Cambridge University Press, 610 pp.

Groot, J. J. \& GROOT, C. R. 1962. Plant microfossils from Aptian, Albian and Cenomanian deposits of Portugal. Comunicações dos Serviços Geológicos de Portugal 44, 133-76.

Haworth, M., Hesselbo, S. P., MCELWAin, J. C., Robinson, S. A. \& BRUNT, J. W. 2005. Mid-Cretaceous $p \mathrm{CO}_{2}$ based on stomata of the extinct conifer Pseudofrenelopsis (Cheirolepidaceae). Geology 33, 749-52.

Hay, W. W., DeConto, R. M., Wold, C. N., Wilson, K. M., Voigt, S., Schulz, M., Rossby Wold, A., Dullo, W.-C., Ronov, A. B., Balukhovsky, A. N. \& SöDING, E. 1999. Alternative global Cretaceous paleogeography. In Evolution of the Cretaceous OceanClimate System (eds E. Barrera \& C. C. Johnson), pp. 1-47. Geological Society of America, Special Paper no. 332.

Heimhofer, U., Adatte, T., Hochuli, P. A., Burla, S. \& WEISSERT, H. 2008. Coastal sediments from the Algarve: low-latitude climate archive for the AptianAlbian. International Journal of Earth Sciences 97, 785-97.

Heimhofer, U., Hochuli, P. A., Burla, S., Dinis, J. M. L. \& WeIsserT, H. 2005. Timing of Early Cretaceous angiosperm diversification and possible links to major paleoenvironmental change. Geology 33, 141-4.

Heimhofer, U., Hochuli, P. A., Burla, S. \& Weissert, H. 2007. New records of Early Cretaceous angiosperm pollen from Portuguese coastal deposits: implications for the timing of the early angiosperm radiation. Review of Palaeobotany and Palynology 144, 39-76.

Herman, A. B. \& SPICER, R. A. 2010. Mid-Cretaceous floras and climate of the Russian high Arctic (Novosibirsk Islands, Northern Yakutiya). Palaeogeography, Palaeoclimatology, Palaeoecology 295, 409-22.

Herngreen, G. F. W. 1973. Palynology of AlbianCenomanian strata of borehole 1-Qs-1-Ma, State of Maranhao, Brazil. Pollen et Spores 15, 51555.

Herrle, J. O., Pross, J., Friedrich, O. \& Hemleben, Ch. 2003. Short-term environmental changes in the Cretaceous Tethyan Ocean: micropalaeontological evidence from the Early Albian Oceanic Anoxic Event 1b. Terra Nova 15, 14-19.

Heusser, L. \& BALSAM, W. L. 1977. Pollen distribution in the Northeast Pacific Ocean. Quaternary Research 7, 45-62.

HochUli, P. A. 1981. North Gondwanan floral elements in Lower to Middle Cretaceous sediments of the Southern Alps (Southern Switzerland, Northern Italy). Review of Palaeobotany and Palynology 35, 337-58.

Hochuli, P. A., Heimhofer, U. \& Weissert, H. 2006. Timing of early angiosperm radiation: recalibrating the classical succession. Journal of the Geological Society, London 163, 587-94.

Hochuli, P. A., Os Vigran, J., Hermann, E. \& Bucher, H. 2010. Multiple climatic changes around the PermianTriassic boundary event revealed by an expanded palynological record from mid-Norway. Geological Society of America Bulletin 122, 884-96.

Hofmann, P., Stuesser, I., WAGNer, T., Schouten, S. \& Sinninghe Damsté, J. 2008. Climate-ocean coupling off North-West Africa during the Lower Albian: the Oceanic Anoxic Event 1b. Palaeogeography, Palaeoclimatology, Palaeoecology 262, 157-65.

Hotton, C. L. \& BAghaI-Riding, N. L. 2010. Palynological evidence for conifer dominance within a heterogeneous landscape in the Late Jurassic Morrison Formation, U.S.A. In Plants in Mesozoic Time: Morphological Innovations, Phylogeny, Ecosystems (ed. C. T. Gee), pp. 295-328. Bloomington: Indianan University Press.

HowARTH, R. J. \& MCARTHUR, J. M. 1997. Statistics for strontium isotope stratigraphy. A robust LOWESS fit to the marine Sr-isotope curve for 0-206 Ma, with look-up table for the derivation of numerical age. Geology $\mathbf{1 0 5}$, 441-56.

Huber, B. T., Hodell, D. A. \& Hamilton, C. P. 1995. Middle-Late Cretaceous climate of the southern high latitudes: stable isotopic evidence for minimal equator-to-pole thermal gradients. Geological Society of America Bulletin 107, 1164-91.

Huber, B. T. \& LECKIE, R. M. 2011. Planktic foraminiferal species turnover across deep-sea Aptian/Albian boundary sections. Journal of Foraminiferal Research 41, 5395.

Huck, S., Heimhofer, U., Rameil, N., Bodin, S. \& IMMENHAUSER, A. 2011. Strontium and carbon-isotope chronostratigraphy of Barremian-Aptian shoal-water carbonates: Northern Tethyan platform drowning predates OAE 1a. Earth and Planetary Science Letters 304, 547-58.

INGRAM， B. L. \& SLOAN, D. 1992. Strontium isotopic composition of estuarine sediments as paleosalinitypaleoclimate indicator. Science 255, 68-72.

Jones, C. E., Jenkyns, H. C., Coe, A. L. \& Hesselbo, S. P. 1994. Strontium isotopic variations in Jurassic and Cretaceous seawater. Geochimica et Cosmochimica Acta 58, 3061-74.

Korte, C., Kozur, H. W., Bruckschen, P. \& Veizer, J. 2003. Strontium isotope evolution of Late Permian and Triassic seawater. Geochimica et Cosmochimica Acta 67, 47-62.

McArthur, J. M., Howarth, R. J. \& Bailey, T. R. 2001. Strontium isotope stratigraphy: LOWESS Version 3. 
Best-fit line to the marine Sr-isotope curve for 0 to $509 \mathrm{Ma}$ and accompanying look-up table for deriving numerical age. Geology 109, 155-69.

Medus, J. 1982. Palynofloristic correlations of two Albian sections of Portugal. Cuadernos Geología Ibérica 8 , 781-809.

Medus, J. \& Berthou, P. Y. 1980. Palynoflores dans la coupe de l'Albien de Foz do Folcao (Portugal). Geobios 13, 263-9.

Mendes, M. M., Dinis, J. L., Gomez, B. \& PAis, J. 2010. Reassessment of the cheirolepidiaceous conifer Frenelopsis teixeirae Alvin et Pais from the Early Cretaceous (Hauterivian) of Portugal and palaeoenvironmental considerations. Review of Palaeobotany and Palynology 161, 30-42.

MOORE, D. \& REYNOLDS, R. 1997. X-Ray-Diffraction and the Identification and Analysis of Clay-Minerals. New York: Oxford University Press, 378 pp.

PELZER, G. 1984. Cross section through fluvial environment in the Wealden of Northwest Germany. In Proceedings of the Third Symposium on Mesozoic Terrestrial Ecosystems, Tübingen, 1984, pp. 181-6.

Pelzer, G., Riegel, W. \& Wilde, V. 1992. Depositional controls on the Lower Cretaceous Wealden coals of northwest Germany. In Controls on the Distribution and Quality of Cretaceous Coals (eds P. J. McCabe \& J. T. Parrish), pp. 227-43. Geological Society of America, Special Paper no. 267.

Peyrot, D., Rodriguez-Lopez, J. P., Lassaletta, L., MELÉNDEZ, N. \& BARRÓN, E. 2007. Contributions to the palaeoenvironmental knowledge of the Escucha Formation in the Lower Cretaceous Oliete Sub-basin, Teruel, Spain. Comptes Rendus Palevol 6, 469-81.

PIERCE, R. L. 1961. Lower-Upper Cretaceous plant microfossils from Minnesota. Minnesota Geological Survey Bulletin 42, 1-86.

Poulsen, C. J., GendaszeK, A. S. \& Jacob, R. L. 2003. Did the rifting of the Atlantic Ocean cause the Cretaceous thermal maximum? Geology 31, 115-18.

PRICE, G. D. 1999. The evidence and implications of polar ice during the Mesozoic. Earth-Science Reviews 48, 183210.

PucÉAT, E., LÉCUyer, C., SHePpard, S. M. F., Dromart, G., Reboulet, S. \& Grandjean, P. 2003. Thermal evolution of Cretaceous Tethyan marine waters inferred from oxygen isotope composition of fish tooth enamels. Paleoceanography 18, 7.1-7.12.

REY, J. 1992. Les unités lithostratigraphiques du Crétacé inférieur de la région de Lisbonne. Comunicações dos Serviços Geológicos de Portugal 78, 103-24.

REY, J. 2006. Stratigraphie séquentielle et séquences de dépôt dans le Crétacé inférieur du Basin Lusitanien. Ciências da Terra, Volume Especial 6, 1-120.

Rey, J., Bilotte, M. \& Peybernes, B. 1977. Analyse biostratigraphique et paléontologique de l'Albien marin d'Estremadura (Portugal). Géobios 10, 369-93.

REY, J. \& CUGNY, P. 1978. Écoséquences et paléoenvironments de l'Albien. Bulletin de la Sociéte d'Histoire Naturelle de Toulouse 113, 374-86.

REY, J., DE GRACIANSKY, P. C. \& JACQUIN, T. 2003. Les séquences de dépôt dans le Crétacé inférieur du Bassin Lusitanien. Comunicações do Instituto Geológico e Mineiro 90, 15-42.

Rocha, F. \& Gomes, C. 1995. Palaeoenvironment of the Aveiro region of Portugal during the Cretaceous, based on clay mineralogy. Cretaceous Research 16, 187-94.

RodrígueZ-LÓPEZ, J. P., MElÉNDEZ, N., DE BOER, P. L. \& SORIA, A. R. 2008. Aeolian sand sea development along the mid-Cretaceous western Tethyan margin (Spain): erg sedimentology and palaeoclimate implications. Sedimentology 55, 1253-92.

Rodríguez-LóPez, J. P., MElÉndez, N., DE BoER, P. L. \& SORIA, A. R. 2010. The action of wind and water in a mid-Cretaceous subtropical erg-margin system close to the Variscan Iberian Massif, Spain. Sedimentology 57, 1315-56.

Ross, N. E. 1949. On a Cretaceous pollen and spore bearing clay deposit of Scania. Bulletin of the Geological Institute, University of Upsala 34, 25-43.

RufFell, A. H. \& BATTEN, D. J. 1990. The BarremianAptian arid phase in western Europe. Palaeogeography, Palaeoclimatology, Palaeoecology 80, 197-212.

SCHNEIDER, S., FÜRSICH, F. T. \& WERnER, W. 2009. Srisotope stratigraphy of the Upper Jurassic of central Portugal (Lusitanian Basin) based on oyster shells. International Journal of Earth Sciences 98, 194970.

SEWALl, J. O., VAN DE WAL, R. S. W., VAN DER ZWAN, K. J., van Oosterhout, C., DijKstra, H. A. \& Scotese, C. R. 2007. Climate model boundary conditions for four Cretaceous time slices. Climate of the Past 3, 647-57.

SolÉ DA Porta, N., Querol, X., CABAnes, R. \& SAlas, R. 1994. Nuevas aportaciones a la palinología y paleoclimatología de la Formación Esucha (Albiense inferior-medio) en las Cubetas de Utrillas y Oliete, Cordillera Ibérica Oriental. Cuadernos Geología Ibérica 18, 203-15.

SRIVASTAVA, S. K. 1977. Microspores from the Fredericksburg Group (Albian of the southern United States). Paléobiologie Continentale 4, 1-119.

STAPLIN, F. L. 1982. Determination of thermal alteration index from color of exinite (pollen, spores). In How to Assess Maturation and Palaeotemperatures (ed. F. L. Staplin), pp. 7-11. Society of Economic Paleontologists and Mineralogists.

Steuber, T., Rauch, M., Masse, J.-P., GraAF, J. \& MALKOČ, M. 2005. Low-latitude seasonality of Cretaceous temperatures in warm and cold episodes. Nature 437, 1341-4.

STOVER, L. E. 1962. Taurocusporites, a new trilete spore genus from the Lower Cretaceous of Maryland. Micropaleontology 8, 55-9.

SuKH-DEV 1961. The fossil flora of the Jabalpur Series 3. Spores and pollen grains. The Palaeobotanist 8, 43-56.

Taugourdeau-Lantz, J., AzÉma, C., Hasenboehler, B., MASURE, E. \& Moron, J. M. 1982. Évolution des domaines continentaux et marins de la marge portugaise (Leg 47B, site 398 D) au cours du Crétacé: essai d'interpretation par l'analyse palynologique comparée. Bulletin de la Sociéte Géologique de France 24, 447-59.

TIRABOSCHI, D., ERBA, E. \& JENKYNS, H. C. 2009. Origin of rhythmic Albian black shales (Piobbico core, central Italy): calcareous nannofossil quantitative and statistical analyses and paleoceanographic reconstructions. Paleoceanography 24, 1-21.

Traverse, A. 2007. Paleopalynology. Dordrecht: Springer, $813 \mathrm{pp}$.

TRINCÃO, P. 1990. Esporos e pólenes do Cretácico inferior (Berriasiano-Aptiano) de Portugal: paleontologia e estratigrafia. Ph.D. thesis, Universidade Nova de Lisboa, Spain, 312 pp. Published thesis.

Tyson, R. V. 1995. Sedimentary Organic Matter. London: Chapman \& Hall, 615 pp.

VAKHRAMEYEV, V. A. 1982. Classopollis pollen as an indicator of Jurassic and Cretaceous climate. International Geology Review 24, 1190-6. 
van KoniJnenburg-van CitTert, J. H. A. \& VAN DER BURGH, J. 1989. The flora from the Kimmeridgian (Upper Jurassic) of Culgower, Sutherland, Scotland. Review of Palaeobotany and Palynology 61, 1-51.

VeIzer, J., AlA, D., AZMY, K., BRUCKSCHEN, P., BuHL, D., Bruhn, F., Carden, G. A. F., Diener, A., Ebneth, S., Godderis, Y., Jasper, T., Korte, C., PAWellek, F., Podlaha, O. G. \& Strauss, H. $1999 .{ }^{87} \mathrm{Sr} /{ }^{86} \mathrm{Sr}, \delta^{13} \mathrm{C}$ and $\delta^{18} \mathrm{O}$ evolution of Phanerozoic seawater. Chemical Geology 161, 59-88.

VillanueVa-Amadoz, U., Pons, D., Diez, J. B., Ferrer, J. \& SENDER, L. M. 2010. Angiosperm pollen grains of San Just site (Escucha Formation) from the Albian of the Iberian Range (north-eastern Spain). Review of Palaeobotany and Palynology 162, 362-81.

VISSCHER, H. \& VAN DER ZWAN, W. A. 1981. Palynology of the circum-Mediterranean Triassic: phytogeographical and palaeoclimatological implications. Geologische Rundschau 70, 625-36.
Wagner, T., Wallmann, K., Herrle, J. O., Hofmann, P. \& STUESSER, I. 2007. Consequences of moderate $\sim 25,000$ yr lasting emission of light $\mathrm{CO}_{2}$ into the mid-Cretaceous ocean. Earth and Planetary Science Letters 259, 200 11

WATSON, J. 1988. The Cheirolepidiaceae. In Origin and Evolution of the Gymnosperms (ed. C. B. Beck), pp. 382-447. New York: Columbia University Press.

WATSON, J. \& SinCOCK, C. A. 1992. Bennettitales of the English Wealden. London: The Palaeontographical Society, $228 \mathrm{pp}$.

WILSON, P. A. \& NORRIS, R. D. 2001. Warm tropical ocean surface and global anoxia during the mid-Cretaceous period. Nature 412, 425-8.

WOODHEAD, J., SweArer, S., Hergt, J. \& MAAS, R. 2005. In situ Sr-isotope analysis of carbonates by LA-MC-ICPMS: interference corrections, high spatial resolution and an example from otolith studies. Journal of Analytical Atomic Spectrometry 20, 22-7. 